\title{
Environmental Conservation in the Tibetan Plateau Region: Lessons for China's Belt and Road Initiative in the Mountains of Central Asia
}

\author{
J. Marc Foggin 1,2 \\ 1 Mountain Societies Research Institute, University of Central Asia, Bishkek 720001, Kyrgyzstan; \\ marc.foggin@ucentralasia.org; Tel.: +996-(0)770-822456 \\ 2 Institute of Asian Research, University of British Columbia, Vancouver, BC V6T 1Z2, Canada
}

Received: 15 March 2018; Accepted: 10 April 2018; Published: 17 April 2018

\begin{abstract}
Environmental conservation has developed significantly in China over the past 20 years, including more collaborative approaches and recent advances in establishing a national parks system. This study reviews the development of protected areas in the headwaters of the Yangtze River, drawing lessons from experiences of community development and co-management approaches. Community engagement and participation in developing localized plans for natural resource utilization and conservation have been critical features of successful ventures. Government programs and policies, the emergence of grassroots civil society, and the development of herders' cooperatives and protected areas, are all tracked, each pointing towards the significant value of inclusive biodiversity conservation approaches for meeting broadly agreed development agendas, such as achieving the Sustainable Development Goals by 2030. Observations from the vast, high, arid, and semi-arid lands of the Tibetan Plateau are then considered in light of China's Belt and Road Initiative, which is bringing vast financial and technical resources to the world. Special attention is given to applying the lessons that have been learned in China to the mountains of Central Asia, globally recognized as a biodiversity hotspot and a water tower for large downstream populations. Keeping local people at the heart of conservation is deemed fundamentally important.
\end{abstract}

Keywords: China; Tibetan Plateau; Sanjiangyuan region; social-ecological systems; pastoralism; partnerships; co-management; national parks; Belt and Road Initiative; mountains of Central Asia

\section{Introduction}

With a global population now exceeding 7.6 billion people and estimated to reach over 11 billion by 2100 [1], humanity consumes significantly more resources than our planet can provide in the long term, and our patterns of consumption and the waste we produce cannot be absorbed by the world's natural systems. In short, our use of natural resources is stretching beyond regenerative capacities [2-5], or even more succinctly, the world has reached planetary limits [6].

The need for sustainability is now agreed by nearly all countries in the world and on this basis a suite of Global Goals (or Sustainable Development Goals) have been adopted to help end poverty, protect the planet, and ensure prosperity for all (see UN Resolution 70/1, Transforming our world: the 2030 Agenda for Sustainable Development [7]). The 17 Global Goals are further developed as 169 targets that we corporately aim to achieve over the next 12 years, and for which everyone will need to play their part: all governments, the private sector, civil society, and citizens alike. Now, with global sustainability perspectives agreed in principle, and many national commitments in place, one final question remains: scale. Of course, it should be at all scales; but therein lies the great challenge. Who will be the winners, and who the losers? In particular, no party should advance "local sustainability" purely 
through an externalization of costs. Conversely, "regional sustainability" should not be achieved through an inequitable transfer of environmental or development burdens between geographic regions, especially if shifting burdens toward those less powerful, remote, or unseen populations. For this reason, comprehensive assessments with multi-stakeholder dialogues and inclusive decision-making processes and governance arrangements are fundamentally important.

With increasing regional and international connectivity (cf. globalization), the approaches adopted and decisions made in one place now almost always impact communities and situations elsewhere, often well beyond the original intended areas or sectors of focus. Additionally, sustainability-oriented goals alone rarely drive all decisions. Political, economic, and environmental factors bring trade-offs such that, at best, we can hope for science-informed, if not actually evidence-based, decisions. Nonetheless, learning from experience and then subsequently feeding the lessons learned into development processes are of paramount value.

With more than 1.4 billion people, China is coping with some of the world's greatest development challenges. It also is demonstrating great technological and scientific innovations and, over the last decade or two, it is become increasingly recognized as a global leader in research and development in numerous fields and disciplines [8-10]. Its growing economic and military strength and increasing global engagement, e.g., through the unprecedented Belt and Road Initiative (in this review paper referred to as BRI, but also known as The Silk Road Economic Belt and the 21st Century Maritime Silk Road, or for short the One Belt, One Road (OBOR) Initiative), also mark China as emerging leading agency in international affairs and global development trends, bringing its own geopolitical dimension to aid [11,12]. In light of its growing influence and geographic reach, how China has been dealing with the governance and management of its natural resources and the mechanisms it has adopted in recent years for achieving conservation and sustainability are very important aspects to consider, as these may be leveraged more widely to increase the overall likelihood of long-term success wherever China invests its time and resources, at home and abroad.

Within China, the Tibetan Plateau encompasses one-quarter of the national territory, and provides many benefits nationally and internationally, especially as ecosystems goods and services from the headwaters of Asia's major rivers. This vast, high altitude mountain landscape is recognized for such values, and much attention and financial resources have been given for environmental protection. However, conserving the natural environment is not contingent only on increased knowledge about nature or ecology or earth systems. It is equally dependent on appropriate understanding of the human or social dimensions of people's livelihoods and the utilization of natural resources, including who decides how resources are used (governance), as well as how they are used (management). The past two decades have seen particularly significant developments in how natural resources are utilized and conserved in the Tibetan Plateau region, including the emergence of community conservation initiatives and the development of a network of protected areas. Building on these experiences, China is now in process of establishing its first national parks, to be launched formally in 2020.

This review paper seeks to follow the development of conservation initiatives, along with local community development within emerging protected areas, over the past couple decades in western China. From this, it aims to draw out some key lessons that could help to inform future programming. How China engages with local communities and how it seeks to balance the overlapping needs and interests of nature and people when undertaking environmental action, will affect not only short-term returns on conservation investment, but also more generally the viability and long-term sustainability of projects and initiatives. Lessons gained from recent experiences in the Sanjiangyuan region of China (referring to the "three rivers sources", i.e., the headwaters of the Yellow, Yangtze, and Mekong rivers) may be applied well beyond protected areas—national parks or otherwise-and should include landscape level conservation and development strategies across western China, as well as neighboring mountainous regions in Central Asia encompassed in the scope of China's BRI.

With its rapidly growing influence around the world, strategic decisions and approaches adopted by China clearly will affect global sustainability. This review article aims to make some of the recent 
experiences in environmental management and conservation more widely known outside China, and to render their links with regional and global sustainability more explicit.

\section{Methods}

Many research methods have been employed over the course of the two decades that it has taken to learn and compile the information, insights, and recommendations presented herein. ${ }^{1}$ Methods have included both qualitative and quantitative approaches: longer time-series, as well as shorter-duration or "snapshot" perspectives; larger sample size household surveys, as well as more in-depth interviews with selected informants and small focus groups; desk reviews of published literature; participatory action research; direct participant-observation; horizontal policy analysis; and other approaches spanning the natural and social sciences. These have been further complemented by a process of continuous reflection on past successes and failures, and renewed consideration of the foundations of sustainable development (e.g., the role of culture as the "fourth pillar" of sustainability $[17,18]$. More details about the interrelated social and ecological contexts encompassed in this review and about the methods adopted in this long-term endeavor are noted elsewhere (e.g., [13,19-24]).

As outlined in a recent documentary about the project work and affiliated research conducted over the past 20 years, upon which the majority of the reflections and recommendations for conservation and sustainable community development presented in this article are based, ${ }^{2}$ the key roles played by the author and his team have included (i) bridging between a range of stakeholders (especially local versus external parties, each bringing different sociocultural, ideological, or economic ideals), which in turn has required (ii) translation between widely differing perspectives and/or worldviews (including scientific versus traditional languages, i.e., ways of seeing the world) and (iii) trialing new ideas or approaches to help address specific problem areas or to more effectively attain common goals in sustainable development, including the conservation of biodiversity. ${ }^{3}$

The analytic frameworks employed in this review paper are multiple, given the breadth of academic disciplines and perspectives, academic and otherwise, that have a bearing on environmental conservation outcomes. Most fundamentally, though, a socioecological systems (SES) framework is adopted, not least because of the wide chasm noted in China, now reducing but still significant, between the natural and social sciences and the differing policy recommendations that ensue. Greater mutual understanding across disciplines through SES-based analyses of the major challenges and benefits of emerging conservation models may lead to more robust syntheses.

The experiences and lessons learned are then further compared and embedded within the wider academic and development literature about community-based conservation and the governance of common property resources, including "co-management" of natural resources and protected areas [26-29]; about indigenous and community conserved areas (ICCAs) [30,31]; and about the need for mainstreaming biodiversity and protected areas within regional development planning [32,33]. This is further complemented by consideration of the wider experiences in conservation and sustainable development in western China [34-38] and in mountainous areas of Central Asia [22,39,40].

1 The author is the founding director of Canadian non-government organization (NGO) Plateau Perspectives, established in 1998, through which the majority of learning opportunities described in this article have taken place. The grassroots organization Upper Yangtze Organization (UYO) was established the same year by Tashi Dorje Hashil. Many of the author's and Tashi Dorje's conservation and development activities were undertaken together or in coordinated fashion, with many learnings taking place in unison. The founding directors' parallel histories and their mutual support and influence on each other are noted elsewhere [13-16].

2 See http:// plateauperspectives.org/documentary/.

3 These three roles (i.e., bridging divides, translating between the different "languages" of culture and science, and providing support through trialing of new ideas or approaches) hold significant overlap with key functions identified for the Chinese environmental NGO Shanshui Conservation Center [25], which has been engaged in conservation programs in the Sanjiangyuan since 2007-namely mediation, translation, and coordination. Both NGOs have sought to enhance local participation in ecosystem management and collaboration amongst actors. 
Insights about China's BRI stem from published literature and media, as well as personal exchanges and interactions with Chinese and non-Chinese colleagues, and participation in recent BRI-related workshops [41-45].

\section{Background}

\subsection{Major Geographies}

This review of the recent history of conservation efforts in China is focused on the Tibetan plateau region, specifically, the headwaters of the Yangtze River in the renowned vast Sanjiangyuan region. Administratively, the Sanjiangyuan is situated in southern Qinghai Province, one of China's largest provincial level units. As with most of western China, climatic conditions are generally arid, human population density is very low (on average $<10$ people $/ \mathrm{km}^{2}$ ) (Figure 1), and most strategic decisions are made in light of a perceived need to strengthen social stability, and security perspectives related to proximity to borderlands. A major transition in development priorities took place in China around 2000, with the country shifting its focus from developing its eastern coastal cities to developing the expansive western hinterlands under the auspices of the Great Western Development Program. Since then, urbanization has continued on massive scale. Over half of the world's population now resides in urban centers, with similar national figures and even faster rates of urbanization occurring in China [46]. The peoples and communities who manage the mountains, grasslands and desert resources in western China, however, remain primarily rural, and often are mainly ethnic minorities within China.

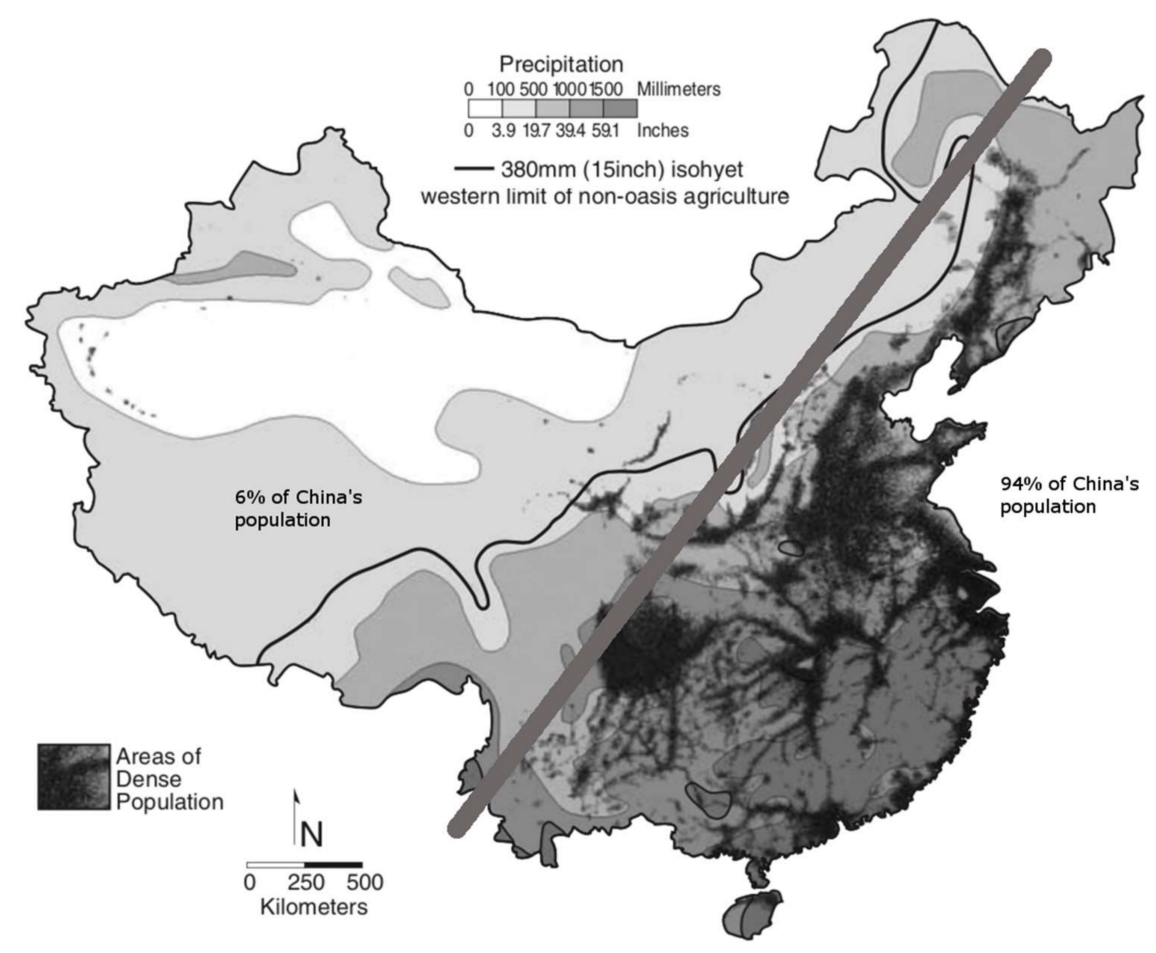

Figure 1. Precipitation and human population in China; showing precipitation isopleths (shading) and highly concentrated areas of human population. Areas north and west of the solid line cannot support agriculture in the absence of irrigation, and hence qualify as "western China." The majority of China's people resides in the eastern half of the country. Adapted from [34], used with permission.

Encompassing around one-quarter of China's land area—or 2.5 million $\mathrm{km}^{2}$ —and with an average elevation over $4000 \mathrm{~m}$ above sea level (asl), the Tibetan Plateau is the largest and highest mountain area in the world. While China itself is recognized as one of the most mega-diverse 
countries in the world [47], the diversity of biogeographic realms and ecosystems that meet or are found in the Tibetan Plateau region make it particularly noteworthy for conservation of global biodiversity. Mountain ranges both bind and transect the Tibetan Plateau, including the Himalayas, Hengduan, Tanggula, Qilian, Kunlun, and Karakoram ranges, which also connect, in turn, with the Pamirs, Hindu Kush, and Tian Shan ranges (Figure 2). Considered together, these contiguous mountainous areas-characterized for millennia by nomadic pastoralism, most prominently yak husbandry [22,48,49]—are more broadly known as High Asia or Greater Central Asia [50-53].

For its part, the Tibetan Plateau per se is often referred to as the Third Pole of the world, because of its vast extent and high altitude [54], also as the Water Tower of Asia, because of the six major Asian rivers that originate on the Plateau [55]. Around 3 billion people live on or downstream of the Plateau [56], and its physical presence and annual snowpack conditions influence the global climate system and Asian monsoon characteristics, respectively. Four major ecosystem types are identified: alpine meadow, alpine steppe, alpine desert, and alpine shrub [57]. Taken together, these vegetative communities form one of the most extensive grazing social-ecological systems in the world [58], home to a unique, diverse assemblage of wildlife [59] and Tibetan livestock that, until recently, provided at least basic sustenance for the majority of herders in this vast highland region [60]. Altogether, around 1.3 million $\mathrm{km}^{2}$ of the Tibetan plateau is classified as steppe (the entire plateau covers around 2.5 million $\mathrm{km}^{2}$, or approximately one-quarter of China's land area), including alpine meadow (45\%), alpine steppe (28\%), alpine desert (5\%), and other types [61].

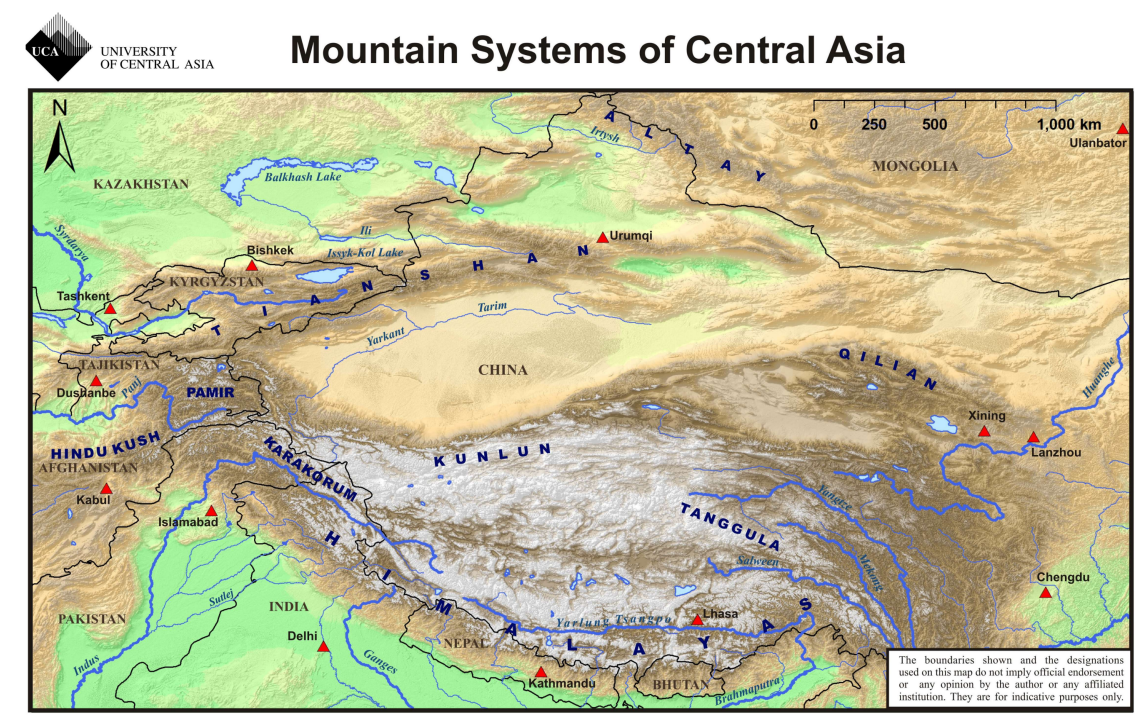

Figure 2. The mountains of western China and Central Asia (Mountain Societies Research Institute, University of Central Asia).

Returning again to the focal area of this review, the Sanjiangyuan region is situated in the heart of the Tibetan Plateau, encompassing the headwaters of the Yangtze, Yellow, and Mekong Rivers (see [13,14,55,62,63]). It comprises $363,000 \mathrm{~km}^{2}$ or around half the land area of Qinghai Province [64] (Figure 3). As an area of great ecological significance to China as a whole, through its biodiversity and its critical water regulatory functions, a large portion of the region was designated as a National Nature Reserve in 2000, encompassing 153,200 $\mathrm{km}^{2}$, or the area of England and Wales combined. Most recently, the decision was made in December 2015 to convert a large area of the nature reserve into China's first national park, to be administered by the central government-the Sanjiangyuan National Park-covering an area of $120,000 \mathrm{~km}^{2}$ [65]. With initial trial operations underway since April 2016, the park management aims to hire at least 10,000 wardens from local herding families to oversee the vast region and to serve as community liaisons, bringing together the dual goals of conservation and socioeconomic development. 


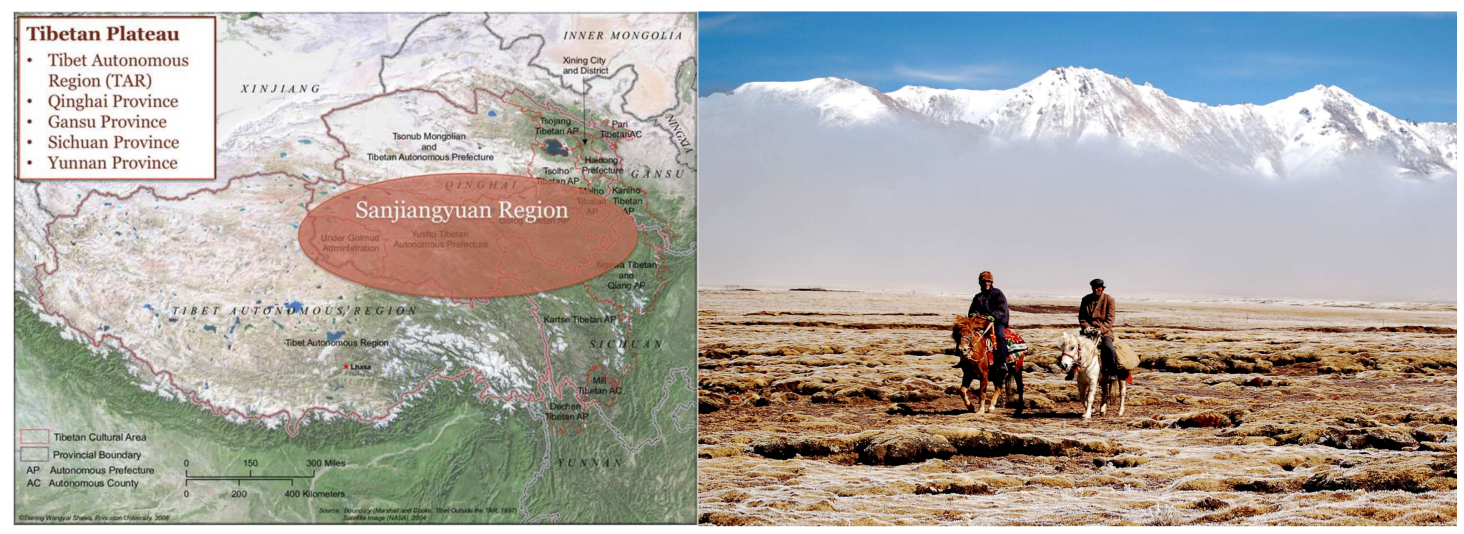

Figure 3. Map of the Tibetan Plateau and Sanjiangyuan (adapted from [66]), and Tibetan pastoralists riding their horses in the high altitude rangeland circa $4600 \mathrm{~m}$ asl near the source of the Mekong River.

However, as elsewhere across the Tibetan Plateau, and in the high mountains of Central Asia, the Sanjiangyuan area and its resident pastoral communities remain vulnerable to a range of factors originating outside its own geography, including the influence of climate change, such as glaciers shrinking and changing seasonality and intensity of precipitation patterns $[63,67-70]$.

\subsection{Protected Areas in China}

China is a mega-diverse country with nearly 35,000 vascular plants (ranking third in the world) and 6445 vertebrate species (7 percent of the world's total) [71,72]. To protect its unique wildlifehalf of China's terrestrial vertebrates are endemic, occurring only in China-the country has established a vast network of nature reserves since 1956, constituting the backbone of China's protected area system. Currently, a total of 2729 nature reserves are spread across the country, encompassing around 15 percent of the territory, with nationally administered reserves covering two-thirds of this area [73]. Altogether, more than 10,000 protected areas (including nature reserves) cover about 18 percent of the country, including forests, geological parks, wetland parks, world natural and cultural heritage sites, and scenic zones [74].

Since 1997, at least seven major protection plans have been developed at national level in China. Developing related laws and regulations, identifying priority areas for biodiversity conservation and key ecological function zones across the country [72], and participation in major conventions, are all constituent parts of these plans. Many positive steps have thus been made in the past few decades for the conservation of China's biodiversity, even while there are some limitations and challenges that clearly remain $[34,72,75]$.

One of the challenges with nature reserves has been to find ways of balancing conservation needs with local communities' socioeconomic aspirations. The development of tourism in protected areas has been trialed in many instances; especially over the past couple decades. However, this approach has brought a range of inherent challenges revolving mainly around the sharing of tourism benefits and commercialization of reserves [76-78], with most instances of tourism development in protected areas being to finance the nature reserves, rather than local development. The overarching goal of nature reserves has remained as "conservation", with most reserve management authorities' interactions with and valuing of resident communities (e.g., for implementing conservation action, such as environmental monitoring or reducing human-wildlife conflict) being mainly pragmatic.

Most recently, China has proposed a new approach to conservation, in line with growing recognition —nationally and globally—of promoting the value of protected areas to not only protect 
biodiversity, but also to secure life-supporting ecosystem services for human benefit. ${ }^{4}$ Aiming to protect special habitats and regulating services while integrating human activities, a new type of protected area is now being introduced in China: the "national park" system (see [71,79]).

Official plans for the national park system clearly indicate that "national parks will be set up... to achieve a combination of ecological protection and sustainable development" [80] and "the biggest difference between a nature reserve and a national park is that the latter offers more social and economic benefits... There should be a balance between protection and utilization in any successful national park, so that it can offer both development opportunities and effective protection" [81]. ${ }^{5}$ The national park system also aims to be a showcase for "ecological civilization", the government's vision for a sustainable relationship with the environment $[82,83]$.

In the first national park — the Sanjiangyuan National Park— "herders and farmers [are expected to] be major forces behind environmental protection [and new] work is expected to provide jobs, boost farmers' incomes and give them an incentive to protect the environment" [80]. According to the Overall Programme for Construction of a National Park System published last year by China's highest level of decision-making bodies, altogether 10 new national parks are being trialed, and will officially be launched in 2020 [82]. As stressed by senior management in China's first national park within this select group (i.e., Sanjiangyuan National Park $[65,84,85]$ ), national parks shall have two distinct, parallel, reinforcing goals: environmental conservation, along with socioeconomic development of resident communities (personal communication, August 2016). The first 10 pilot national parks currently being developed in China $[79,86,87]$ are introduced in Table 1.

Table 1. National Parks (NP) in trial development phase in China's new national parks system.

\begin{tabular}{|c|c|c|c|}
\hline Name & Province & Description & Total Area \\
\hline Sanjiangyuan NP & Qinghai & $\begin{array}{l}\text { The first and largest of the } 10 \text { pilot national parks, encompassing the } \\
\text { headwaters of } 3 \text { major rivers: the Yellow, Yangtze, } \\
\text { and Mekong rivers [88] }\end{array}$ & $123,100 \mathrm{~km}^{2}$ \\
\hline Great Wall NP & Hebei & $\begin{array}{l}\text { The only NP in China that is being built around cultural heritage, } \\
\text { including the Ming Dynasty Tombs and Badaling Great Wall [89] }\end{array}$ & $60 \mathrm{~km}^{2}$ \\
\hline Pudacuo NP & Yunnan & $\begin{array}{l}\text { Renowned for its primitive landscape including lakes, wetlands, } \\
\text { forests, and meadows, as well as nearly } 100 \text { endangered wildlife } \\
\text { species. Very rich in biodiversity, it contains over } 20 \text { percent of } \\
\text { China's plant species and around } 1 / 3 \text { of its mammals and birds. } \\
\text { Home to black-necked cranes, orchids, and Himalayan Yew. } \\
\text { Tibetan culture and customs also are component parts of the NP. }\end{array}$ & $1313 \mathrm{~km}^{2}$ \\
\hline Qianjiangyuan NP & Zhejiang & $\begin{array}{l}\text { Includes habitat of threatened endemic species such as Elliot's } \\
\text { pheasant and tufted deer. Known for seed plants. }\end{array}$ & $252 \mathrm{~km}^{2}$ \\
\hline Mount Wuyi NP & Fujian & $\begin{array}{l}\text { Known for deep canyons, dense subtropical forests, waterfalls, } \\
\text { and wildlife. One of China's most famous, beautiful landscapes. } \\
\text { A World Heritage Site. }{ }^{2}\end{array}$ & $983 \mathrm{~km}^{2}$ \\
\hline
\end{tabular}

4 China has been protecting wildlife for many decades through a system of nature reserves and other protected areas. However, the value (or benefit) of such protected areas for human wellbeing has not always been considered explicitly. Until China's leadership recognized the integral relationship between people and nature even within protected areas, the "national park" system could not have developed. (Note: The term protected area is a high level generic category for all forms of de jure and de facto protection of the natural environment. Nature reserves constitute one form of protected areas, which prioritize the protection of wildlife and habitats, but without direct consideration of human wellbeing. On the other hand, national parks have a dual mandate to protect nature as well as to benefit people.) In China, a deeper understanding of "the environment" as coupled socio-ecological systems (SES) has emerged only in recent years. In the case of Sanjiangyuan region, an SES perspective has emerged as partners have jointly explored more collaborative models of conservation. Ultimately, it was decided that a national park model of conservation-with its dual mandate-was the most appropriate form to adopt for addressing both the ecological significance (and need for protection) and human development interests in the region.

5 Both national parks and natures reserves are legal entities in China. Development of the national parks system aims to centralize and "rationalize" the planning and management of nationally prioritized areas. On the other hand, the legal home (government agency) and modes of operation of nature reserves is much more diverse. As for "community conserved areas", this term is more descriptive than legal in China; but is now well recognized by the International Union for the Conservation of Nature (IUCN) and other agencies internationally. 
Table 1. Cont.

\begin{tabular}{|c|c|c|c|}
\hline Name & Province & Description & Total Area \\
\hline Shennongjia NP & Hubei & $\begin{array}{l}\text { Well known for vast primeval forests, large numbers of endangered } \\
\text { species and varieties of medicinal herbs, and legends such as the } \\
\text { mysterious "Wild Man". Situated near China's Three Gorges. } \\
\text { Largely karstic, with many caves. A World Heritage Site. }{ }^{3}\end{array}$ & $1170 \mathrm{~km}^{2}$ \\
\hline Mount Nanshan NP & Hunan & Stopping point for tens of thousands of migratory birds. & $619 \mathrm{~km}^{2}$ \\
\hline $\begin{array}{l}\text { Siberian Tiger and } \\
\text { Siberian Leopard NP }\end{array}$ & $\begin{array}{l}\text { Jilin and } \\
\text { Heilongjiang }\end{array}$ & $\begin{array}{l}\text { The park covers one-quarter of the area of the Siberian tiger and } \\
\text { Siberian leopard (hubao) habitats in China and over } 75 \% \text { of the } \\
\text { animals' wild population }[82,90,91] \text {. }\end{array}$ & $14,600 \mathrm{~km}^{2}$ \\
\hline Giant Panda NP & $\begin{array}{l}\text { Sichuan, Gansu, } \\
\text { and Shaanxi }\end{array}$ & $\begin{array}{l}\text { More than } 80 \text { protected areas will be incorporated into this park, } \\
\text { home to most of the world's giant pandas (daxiongmao), along with } \\
\text { much other wildlife. }\end{array}$ & $27,000 \mathrm{~km}^{2}$ \\
\hline Qilian Mountains NP & $\begin{array}{l}\text { Gansu and } \\
\text { Qinghai }\end{array}$ & $\begin{array}{l}\text { High altitude mountain range (at } 4000 \text { to } 6000 \mathrm{~m} \text { asl) with meadows, } \\
\text { forests, glaciers, and rugged landscape. Home to snow leopard, } \\
\text { white-lipped deer, and other rare wildlife species. }\end{array}$ & $50,000 \mathrm{~km}^{2}$ \\
\hline
\end{tabular}

The emerging perspective in China about the multiplicity of roles and the major objectives of protected areas (i.e., beyond strictly protectionist approaches to conservation, as exhibited in the development of the new national park system) is consistent with the country's long-term commitment to the UN Convention on Biological Diversity (CBD) and the more recent UN Sustainable Development Goals (SDGs). A strategic mainstreaming of ecological protection across all development sectors was first apparent in China's "ecological red line" approach [74,82,92,93], reinforced by programs such as the Global Environment Facility-supported (GEF) suite of biodiversity- and protected areas-strengthening projects at provincial and national levels. About half of the total land area in western China is encompassed within the 25 national key ecological function zones (Figure 4), each prioritizing conservation functions for water source areas, soil and water, windbreaks and sand fixation, or biodiversity [94].

The value of protected areas for achieving the SDGs is now well established [95-98], as is China's commitment to the SDGs $[99,100]$ and the tightly connected Paris Accord [101].

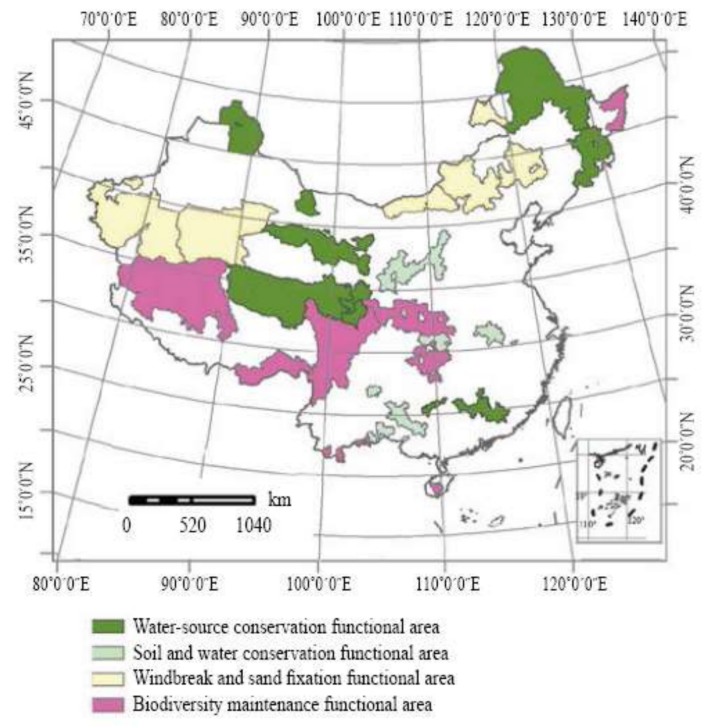

(a)

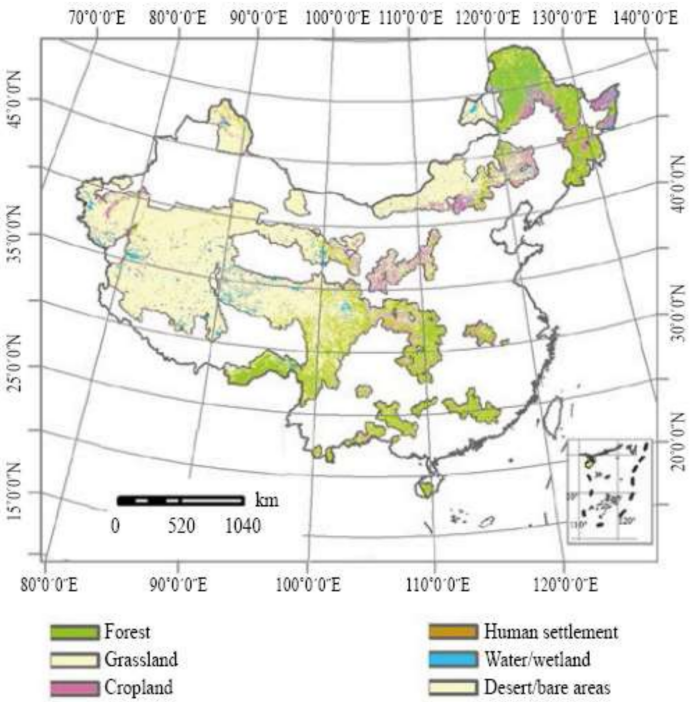

(b)

Figure 4. China's strategy of National Key Ecological Function Areas, according to (a) functional areas and (b) major ecosystems [91]. Used with permission. 


\section{Results}

\subsection{Recent Developments in Conservation and Sustainable Use of Tibetan Rangelands (Case Study)}

Across the Sanjiangyuan region in southern Qinghai Province, traditional nomadic pastoralism, and to a lesser extent, subsistence hunting, have been practiced for at least 5000 years [19,55]. Moving from tribal feudalism (until circa 1958) to collectivism (circa 1958-1978) to quasi-privatization of land and privatization of livestock (from 1978 to present), local forms of pastoralism have seen major transformations in less than a lifetime. Nomadic pastoral practices have, by and large, given way to more sedentary lifestyles, and in many instances to people's permanent relocation and urbanization (Figure 5). Many elements of the former seasonal mobility of livestock grazing and flexibility in the resource management system are now largely gone, with reduced social resilience to shocks and stressors, including climate change. That being said, local sociocultural, political, and economic opportunities and local adaptations remain dynamic in the region; as the author has witnessed on multiple occasions in the Yangtze River headwaters, from 1998 to present [13,19,55,102].

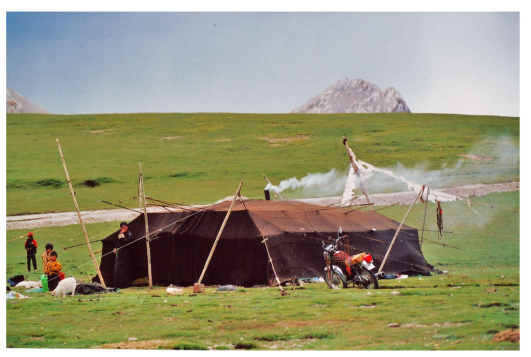

(a)

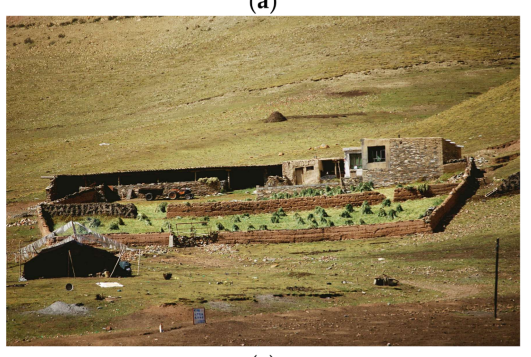

(c)

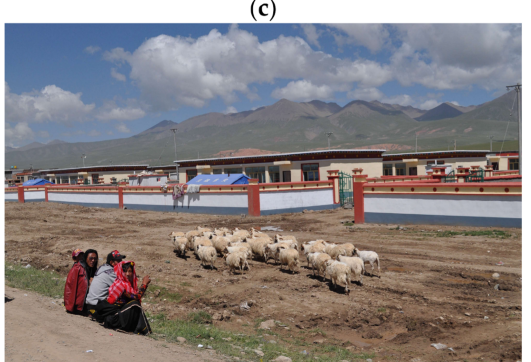

(e)

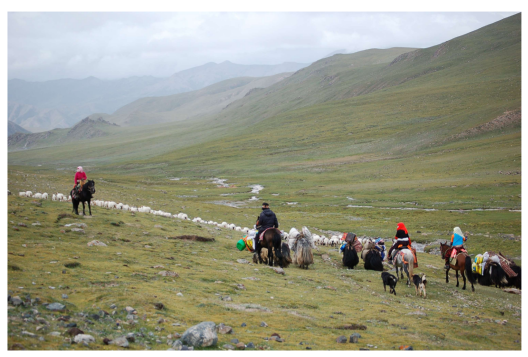

(b)

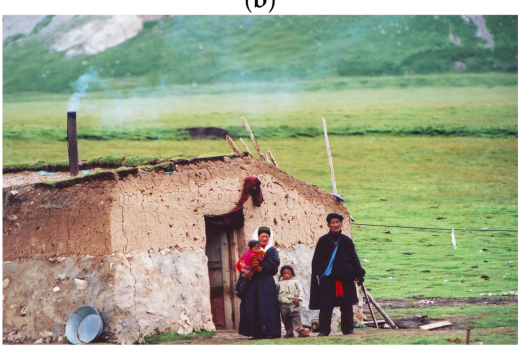

(d)

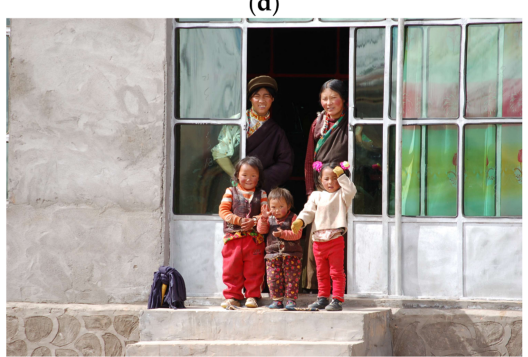

(f)

Figure 5. The last two decades have seen major changes in pastoral practices and people's livelihoods in the Sanjiangyuan region, shifting from traditional nomadic pastoralism on the vast grasslands up until the 1990s and early 2000s; to sedentarization, with construction of winter homes and introduction of agricultural practices (mostly for winter fodder) in the mid-2000s; to full relocation and settlement of a large portion of the population in new villages built under the eco-migration policy. Photo descriptions: (a) Tibetan family and yak hair tent on the grasslands; (b) pastoralist family moving to summer pastures; (c) winter dwelling of a Tibetan pastoralist family, including winter home, livestock shelter, and agricultural field; (d) family living in converted livestock shelter; (e) "nomads without pastures" in a recently built relocation village; (f) Tibetan "nomad" family, formerly livestock herders, now living in a relocation village. 
Locally and around the world, traditional practices and perspectives are now increasingly recognized as converging with so-called more modern or scientific approaches [103-105]. In many places, an appreciation for complementary ways of seeing and knowing the world around us is becoming increasingly mainstream, and dialogue is starting to occur across former sociocultural divides. In the Tibetan plateau region, climate change is now being noted, and sometimes even documented, by herding communities. Much potential also exists for further development of "citizen science" to strengthen dialogue and collaborative studies, with partners coming from diverse educational and sociocultural backgrounds. Both recognizing and maximizing benefits of different "ways of knowing" have long been at the heart of this case study, whereby the author and colleagues have proactively sought to bridge different worlds [106] and to champion for effective restoration of "sense of ownership" to local communities [107].

Since 1998, the following developments have been particularly noteworthy for the management and conservation of the grassland social-ecological systems highlighted here, including their biodiversity and the social and livelihood practices of local communities. Transformations also have been taking place at the science-society interface. This is especially evident with the meeting of "scientific development" from Chinese national planners and government agencies, on one hand, and more traditional views and practices of herding communities, on the other hand, through a collaborative approach generally known as "community co-management" of natural resources and protected areas.

The following major developments from the past two decades together constitute a high-level review of recent history of conservation and environmental management in western China, as expressed in the particulars of the Sanjiangyuan region of the Tibetan Plateau.

\subsubsection{Community Conserved Areas and the Development of Local Civil Society}

Five local protected areas were created in 1998, established by community members in the Suojia district (former commune) in western Zhiduo County to protect endangered wildlife $[13,19]$ (Figure 6). Although later incorporated into the Sanjiangyuan National Nature Reserve (and ultimately, the Sanjiangyuan National Park), their origins and ongoing operations have largely remained with the local herding communities themselves, who began to monitor local wildlife before any official protected area was established. The species focus built on a local cultural appreciation of wildlife as jewels of the land ${ }^{6}$ including the snow leopard (Panthera uncia), Tibetan antelope (Chiru hodgsoni), wild ass or kiang (Equus kiang), wild yak (Bos mutus), and black-necked crane (Grus nigricollis).

Development of these community conserved areas occurred simultaneously with the establishment of the grassroots non-government organization (NGO), Upper Yangtze Environment and Development Organization, or Upper Yangtze Organization (UYO) for short, established in 1998. This NGO brought together more than 100 local community members for common purpose, with special emphasis on wildlife conservation and so-called "green development" (i.e., environmentally sound development) $[13,19,103]$. Embedded within a sociocultural ethic of conservation and a longer local history of activism - from the work of Sonam Dorje and the Wild Yak Brigade [108-110], to community-wide mobilization led by the UYO [13,21,33] and the establishment and operation of village-level tent schools and health centers (see [111,112] and subsequent annual reports, ${ }^{7}$ also [23,24]; Figure 7) — the various activities and approaches initially adopted in Muqu community contributed to setting the scene for community based conservation in the Yangtze River headwaters. Under the leadership of Tashi Dorje Hashil, work undertaken by Snowland Great Rivers Environmental Protection Association (SGREPA [15]) has been instrumental in taking these and other community approaches even further, scaling them up and extending across the province.

6 For participatory video created by Muqu community, see http://www.marcfoggin.com/participatory-video/. 7 To download Plateau Perspectives' Annual Reports 2005-17, see http:/ / plateauperspectives.org/downloads/. 
Following establishment of the UYO, several other communities followed suit and established their own organizations or associations, often encouraged by the charismatic leadership of a few individuals through trusted relationships built over time. Most recently, a network of more than 30 local innovative thinkers and conservation leaders across the province have been recognized as conservation heroes for their sustained efforts [16,113].

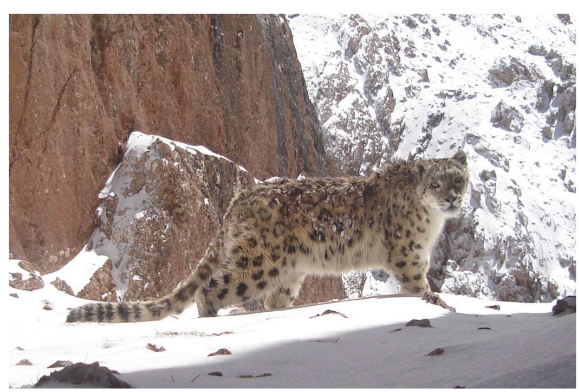

(a)

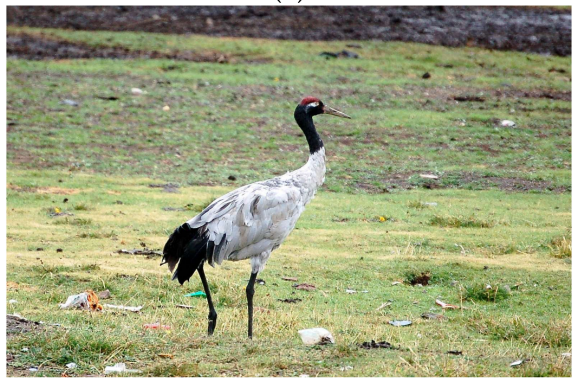

(c)

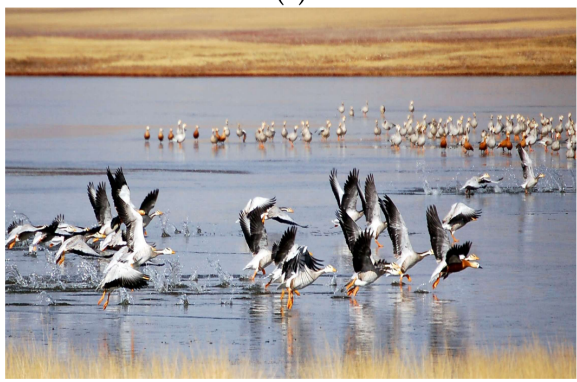

(e)

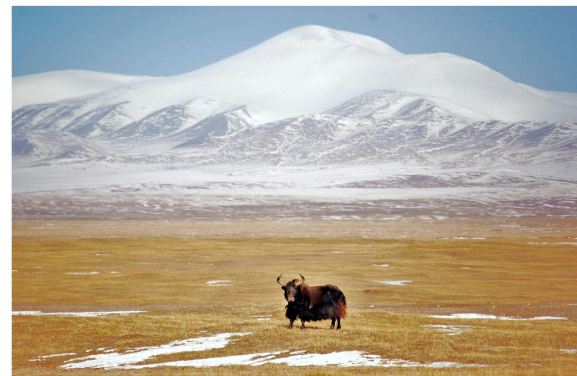

(b)

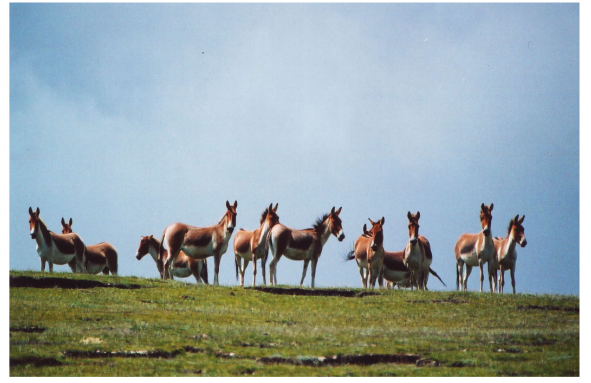

(d)

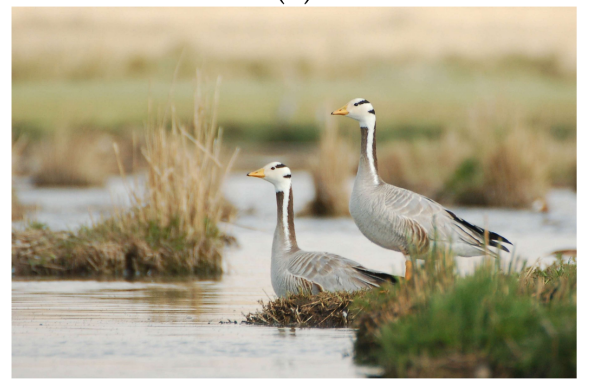

(f)

Figure 6. Endangered wildlife protected by local herding communities includes (a) snow leopard, (b) wild yak, (c) black-necked crane, (d) wild ass, and (e) wetland birds, including (f) bar-headed geese.

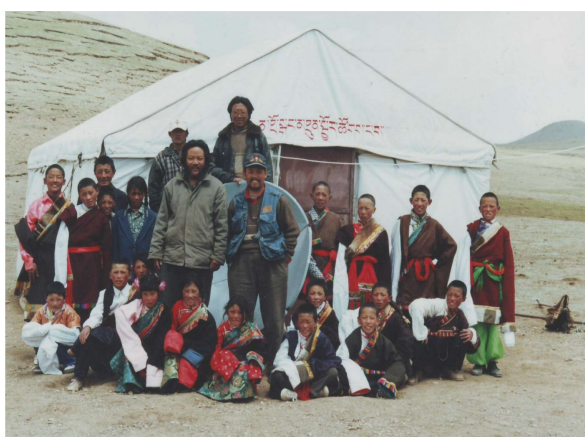

(a)

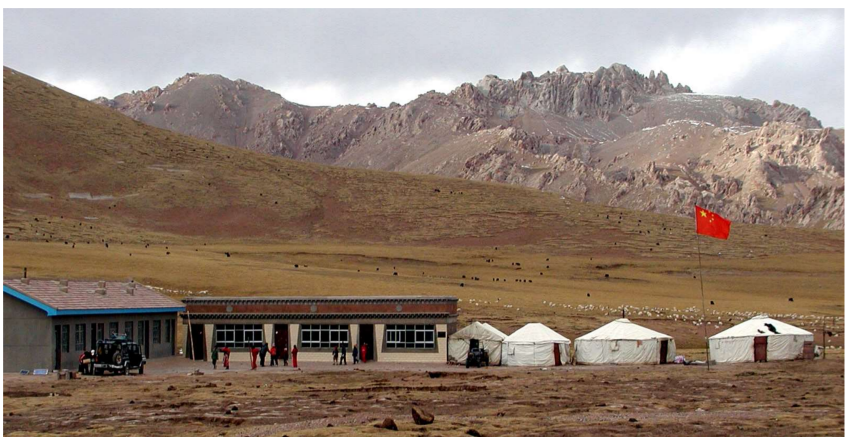

(b)

Figure 7. The Muqu village tent school was established circa 2000, shown here (a) with first intake of students and (b) in its final location, including permanent buildings, with prime snow leopard habitat in the background. 


\subsubsection{Sanjiangyuan National Nature Reserve and Community Co-Management}

Shortly after the above community-based protected areas were established, the Sanjiangyuan National Nature Reserve was announced, formally established in 2000. However, local Tibetan communities now found themselves living within a nature reserve, with a new suite of official regulations affecting their lives, yet having had very little, if any, involvement in its planning and establishment. With initially no provision for involvement in its management, the herders residing in the Yangtze River headwaters became deeply concerned about their future. It is only with an intentional process of multi-stakeholder dialogue in the first few years of the reserve's existence that the management authorities came to recognize both the potential roles and multiple benefits that could be derived from developing partnerships with herding communities. Thus was initiated what has become the main modus operandi of the reserve, "community co-management" (Figures 8 and 9).

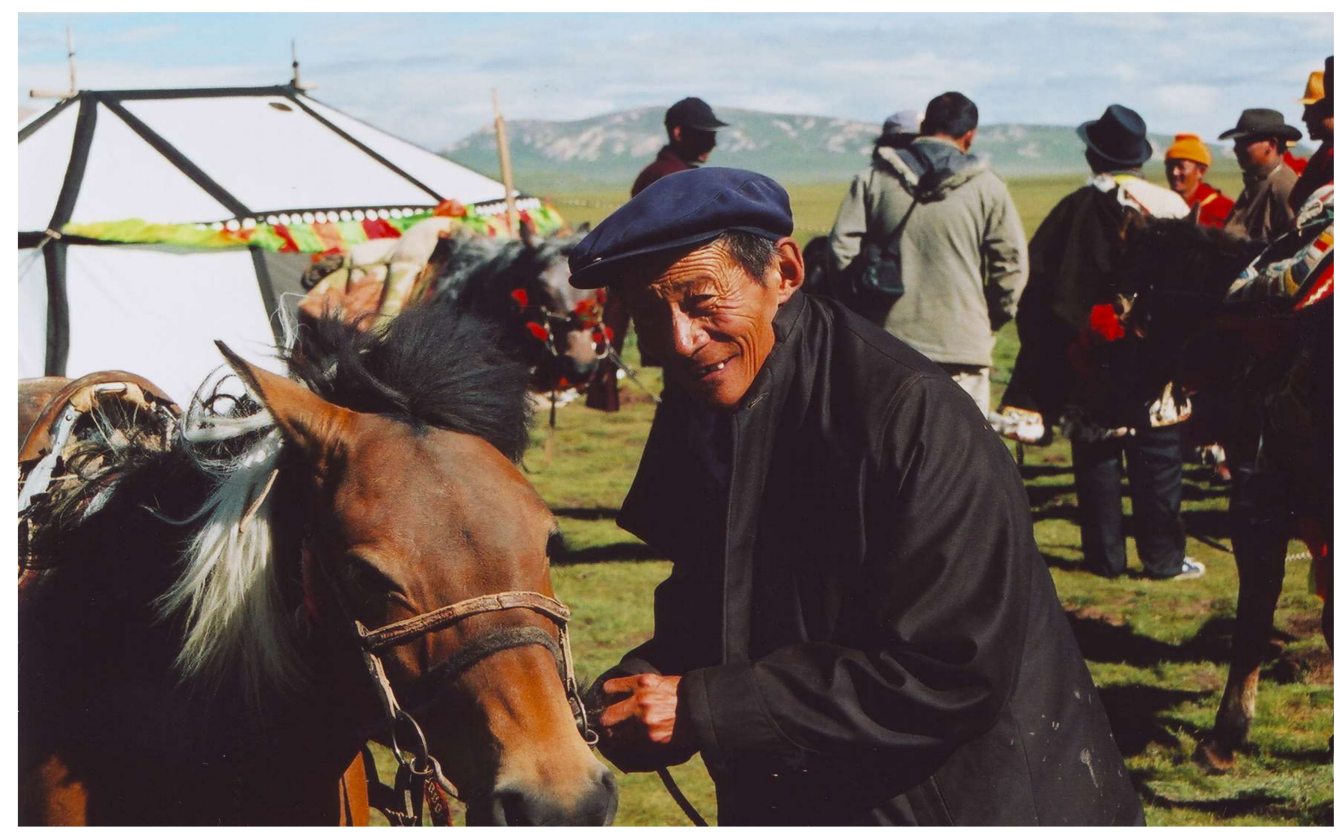

Figure 8. Jiongqu village leader at a co-management planning meeting on the grassland, circa 2007.

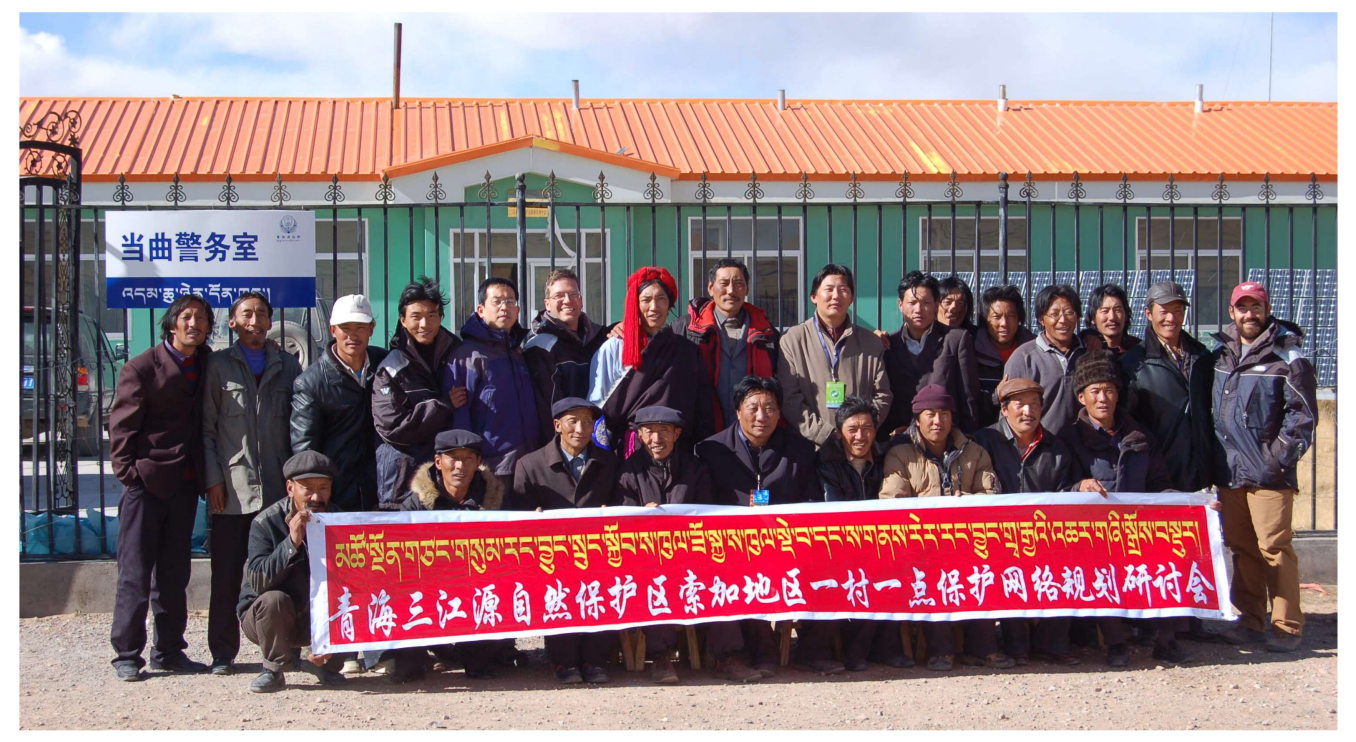

Figure 9. Co-management meeting with nature reserve and village representatives, October 2007. 
The decision to adopt a co-management approach was made for four main reasons: (i) to compensate for a shortage of field staff, (ii) to capitalize on local herders' knowledge and abilities, (iii) to increase environmental awareness, and (iv) to reduce illegal poaching. In addition to these four reasons, the author and his team also sought to advance this approach because (v) such dialogue and partnership would help empower and build the capacities of the local community, and (vi) actual demonstration of partnership-in-action could be used to highlight to policy makers how local communities may be partners in conservation, i.e., seen as part of the solution, rather than assumed (wrongly) to be primarily detrimental in areas of high biodiversity value.

As the national nature reserve's core zones were geographically overlapping with the community-based conservation areas, there was high risk that the national plan for conservation would in fact negate the community's plans and goodwill for contributing to environmental monitoring, raising environmental awareness, conducting anti-poaching patrols, etc.-all heretofore undertaken on voluntary basis by the community members.

At a planning workshop in October 2005 that included nature reserve management authorities, community representatives, local government, and selected international experts familiar with protected areas and their management, grassland ecology, and wildlife research [14], an arrangement was agreed between the nature reserve, the international NGO Plateau Perspectives and Muqu community, whereby co-management would be trialed through a joint monitoring and conservation project revolving around community based snow leopard monitoring, research, and conservation [14,114-117]. Training workshops and data collection by local community members subsequently took place over several years, leading to a clear demonstration of the value of sustained partnerships for conservation purposes $[21,118] .{ }^{8}$ Earlier direct observations of snow leopard and their sign by community members was subsequently extended with use of camera traps as collaborative projects intensified $[66,116,119,120]$.

In another herding community near the source of the Yangtze River, village level regulations were agreed as early as 1998 to limit illegal poaching by local and external hunters-several years before creation of the Sanjiangyuan National Nature Reserve. Over time, this led to the establishment of a local organization, Friends of Wild Yak Association. This community venture was subsequently incorporated into the "contract conservation" model that was trialed by the nature reserve in its broader community co-management framework $[25,118,121]$. In this approach, a contract is agreed between the local community and reserve authorities, whereby local community rangers monitor wildlife populations (in this instance, wild yak) in exchange for agreed payments into a local community-managed development fund. Both this and the aforementioned snow leopard monitoring and conservation work were explicitly referenced in the early preparatory phase of the GEF-supported UNDP Qinghai Biodiversity Conservation Project, implemented by the Qinghai Forestry Department (2013-2017) (see [122]) as the positive experiences of co-management that should be scaled up by the project and integrated into future operations.

Through these collaborative approaches, threats such as poaching have greatly diminished, wildlife observations are reported to government conservation authorities, local awareness and pride in wildlife have increased through school-based and other outreach activities, and local communities' sense of empowerment has extended beyond environmental conservation action, per se. Fortunately, beyond these social outcomes (which remain critically important and the primary focus of this review paper), biodiversity benefits also have accrued over time, with increasing wildlife populations being reported (personal communications, repeated from several community members, as well as several field staff and leaders of the Sanjiangyuan nature reserve and national park).

8 See Snow Leopard Community Conservation Project, http://plateauperspectives.org/en/project/snowleopard/. 


\subsubsection{Community Associations and Cooperatives}

Just beyond the boundary of the nature reserve, another herding community also was mobilized in 2010. Encouraged by two young charismatic community members, the Kegawa Herders Cooperative (named after a local sacred mountain) was established in 2010 (see [102,117,123-126]), in addition to a local community association that successfully trialed the operation of a revolving development trust fund $[123,124,127,128]$. Both the county and prefecture governments provided the enabling policy environments, but actual development of these efforts has been largely endogenous.

The launch of the Kegawa Herders Cooperative marked the beginning of what has been one of the most empowering development activities seen in the region since the author first visited in 1998. Starting with around 40 families, now over 90 households regularly participate in the projects and activities organized by the cooperative. These activities include regular monitoring of grassland conditions, development of handicrafts, operation of a small shop, and ongoing development of a community-based tourism venture. Long-term partnership also has developed with an international clothing company, kora, which produces high quality thermal clothing from fine yak wool. Through this partnership, all members of the cooperative have the option to sell their yak wool at guaranteed upper fair market value. The cooperative makes major decisions at annual general meetings and operates activities through working groups. Membership is purely voluntary, but requires some financial contribution, and annual payment of dividends (from profits generated over the year) is proportional to each member's contribution, whether financial or in-kind, e.g., livestock. General meetings are held annually, and ensure that every member has a voice, based on a principle of one person, one vote. Working groups have been established to oversee regular operations and facilitate ongoing communication amongst members, including in ecological husbandry, grassland monitoring, environmental awareness, garbage collection, tourism development, and other topics. Some profit generated from activities is reinvested into the core fund, and some is earmarked for social needs. Most recently, in late 2015, the cooperative has decided to develop its own yak herd, together with designated pastureland. Sale of milk, butter and cheese is planned, targeting mainly the expanding urban population in the county capital.

A separate community association with a revolving fund mechanism to support small businesses was also established in a nearby village, providing another way by which to strengthen local communities in natural resource governance, business development, and community-wide negotiations. Through provision of micro loans, three rounds of ventures were successfully trialed. Beyond the individual activities funded, the broader success of this community revolving fund project was the mobilization of community members to jointly discuss, agree, and implement development action. Specifically, external capital was provided to create a trust fund, and members of the association were trained in project planning, monitoring, multi-stakeholder meetings, financial management, and other skills necessary to operate this venture. Formation of an association was necessary to provide the legal basis of operations and to enable user groups to convene and establish clear and transparent operational procedures (Figure 10). After running community management trainings and project operations for several years, the $100 \%$ payback of the short-duration loans instilled confidence to launch follow-up revolving fund projects in additional pastoralist communities in the Yangtze River headwaters (personal communication, Du Fachun, August 2016).

For the government, both approaches outlined above demonstrate the viability of community-based management of resources, including financial resources. This could become even more important in the future as new options for transfer payments are considered (i.e., eco-compensation) for local pastoralists, in exchange for protection and maintenance of critical ecosystems services in China's rangelands. The county government already has assimilated many of the learnings from these experiences and has integrated them into its broader poverty alleviation work and economic development planning for rural areas (personal communication, Gongbo Tashi, August 2016). In a world that is increasingly "flattened" by globalization, which tends to encourage homogeneity 
over sociocultural diversity, empowerment and sense of identity are themselves inherently important ingredients for people's wellbeing.

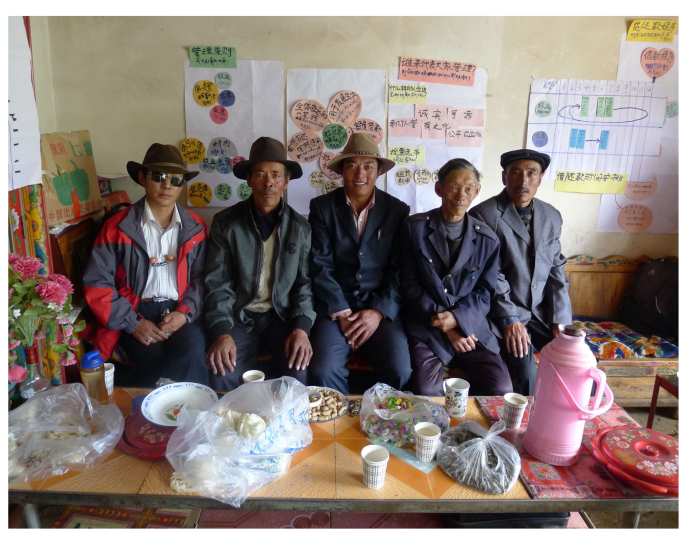

(a)

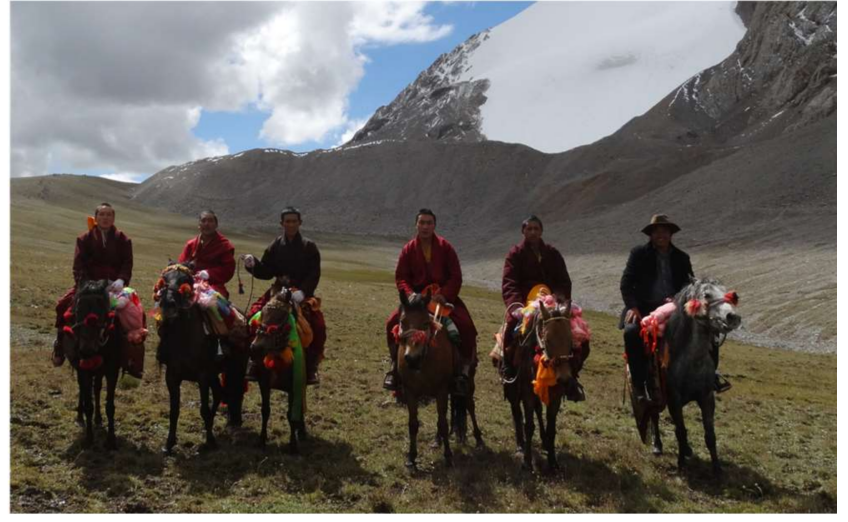

(b)

Figure 10. Two community ventures: (a) Lari community development revolving fund management group (photo: Du Fachun) and (b) tourism development and glacier monitoring by Kegawa Herders Cooperative (photo: Jigme Rabden).

\subsubsection{Development of China's New National Park System}

The dual overarching purposes of national parks in China have already been highlighted—aiming to conserve the environment while simultaneously promoting community development and wellbeing. As such, developing national parks (as compared to nature reserves, with their stricter conservation focus) has come as a natural progression, incorporating local interests and concerns of both parties, government and communities. The Sanjiangyuan National Park will open formally in the year 2020, with other national parks to follow soon after $[85,129]$. While guided and overseen centrally, the daily operations of national parks will be delegated to local government, along with other partners if co-management approaches are maintained.

Over the past couple decades, the major contributions made to the development of the national parks system in China has been the trialing of community co-management, thereby integrating a focus on community-level development needs and interests into hitherto primarily conservation-only deliberations for protected area management. This has included, inter alia, community involvement in wildlife monitoring, awareness and outreach including community wildlife festivals, support for the provision of rural health and education services, mitigation of human-wildlife conflict (especially by brown bear), support for local development mechanisms such as community level associations and cooperatives and the brokering of international partnerships with them (e.g., with kora ${ }^{9}$ ), and the organization of strategic study tours to Mongolia, Canada, and Nepal (each with strong emphasis on development of national parks, including co-management approaches, the need for monitoring and research, and opportunities and challenges related to tourism in the framework of protected area) (see [111] and subsequent annual reports; also [23,24,130,131]). Through these many areas of collaboration between the nature reserve, local community members and international partners, and the valuable deliberations they have enabled from 1998 to present, a new vision began to emerge about the possibilities offered by a national park model, understood to be more inclusive of community needs and interests.

Moving forward, it will be especially important to find ways to strengthen the greatest asset in the Sanjiangyuan National Park—its 10,000 strong "work force" of community-based field staff.

9 See the high performance technical clothing company kora, http://www.kora.net/row/our-story/. 
Notably, these staff will serve not only as environmental monitors, but more broadly as park wardens and as liaisons to the wider communities of which they are a part. As such, they should be empowered and strengthened to assist their own communities in matters of socioeconomic development, as well as reaching the conservation goals of the national park. Their capacities should be developed through trainings, and appropriate tools should be provided to enable them to accomplish all the functions assigned or adopted by them. In regard to the management objectives of the park, particularly the management of its wildlife and habitat resources, the collection of data will necessarily remain of paramount importance, as resources cannot be managed if their status and trends are unknown. Given the vastness of the Sanjiangyuan National Park and the large but dispersed population, the management authorities are presently considering how best to meet the need for large repeated-measure datasets, and how the new community wardens could assist in this. Particular attention is now being given especially to the potential use of the ubiquitous smartphone, and increasing local cell phone coverage, along with emerging information and communication technologies (ICT) such as "citizen science"-enabled digital field guides (e.g., Lapis Guides as a data collection tool [132]). ${ }^{10}$ The development of long-term partnerships between local community members and national park management authorities for joint action could, with suitable tools and "translation" mechanisms (between community-based observations and traditional knowledge, on the one hand, and scientists and science-informed managers, on the other hand), provide substantial returns on investment for formal (i.e., government) conservation authorities, through creation of "big data" (personal communication, Gongbo Tashi, February 2018) as well as the empowerment of local communities as partners in conservation [22,133,134].

\subsection{Lessons Learned for Environmental Conservation, 1998-2018}

In the previous section, this article has tracked themes of biodiversity conservation and sustainability on the Tibetan Plateau, from 1998 to present, through the lens of community conservation ventures, the development of a unique network of protected areas, and affiliated community mobilization and socioeconomic development mechanisms. We can learn much from comprehensive, retrospective analysis of such unique development experiences, even beyond the intentional "participatory action research" orientation set out at the beginning. Moreover, these valuable lessons, summarized in Table 2, can be applied to strategic planning and decisions about the design and management of protected areas and natural resources in the future.

Furthermore, as China expands the scope of its influence, as is now occurring through the high stakes Belt and Road Initiative, "putting its best foot forward" will benefit the neighboring mountain regions and societies in Central Asia, as well as mark China more favorably on the global scene.

What has been learned from the above experiences? What key lessons can be captured and shared?-both for the strengthening of China's new national park system, now in development, and also for transferring into China's wider spheres of engagement, such as with neighboring countries through its multi-national Belt and Road Initiative (BRI).

Below are a series of key lessons that have been learned since 1998 through practical, hands-on experience working in partnership with Tibetan herding communities in the Sanjiangyuan region in western China. Each lesson represents an important element to be considered and encouraged as a core principle of community development and sustainable livelihoods (see e.g., [135-139]).

10 For smartphone application to develop citizen science field guides, see Lapis Guides, http://lapisguides.org/. 
Table 2. Lessons learned from recent conservation history in the Sanjiangyuan region, 1998-2018.

\begin{tabular}{lcc}
\hline \multicolumn{1}{c}{ Major Lessons } & for National Parks and Other Protected Areas & for BRI \\
\hline Comprehensive perspectives are essential & $\sqrt{ }$ & $\sqrt{ }$ \\
Conservation champions are major players & $\sqrt{ }$ & $\sqrt{ }$ \\
Community ownership increases commitment & $\sqrt{ }$ & $\sqrt{ }$ \\
Community participation increases effectiveness & $\sqrt{ }$ & $\sqrt{ }$ \\
Community co-management helps to build trust & $\sqrt{ }$ & \\
Cooperatives and associations are effective tools & $\sqrt{ }$ & \\
Citizen science can serve as a connecting bridge & & \\
\hline
\end{tabular}

\subsubsection{Comprehensive, Integrated Perspectives Must Be Adopted}

An integrated perspective of environmental conservation and development goals across multiple user groups and other stakeholders, with simultaneously conflicting and concurring outlooks and purposes, will allow better assessment of the major opportunities and trade-offs for community development. Overall, a more nuanced understanding and appreciation of all different stakeholder groups' perspectives are necessary precursors for developing genuine, viable and lasting partnerships. An appreciation that people, communities, and cultures are to some extent "tied to the land" and work as part of broader socioecological systems, rather than as external agencies, also will aid in development of viable models for more sustainable, community-oriented development [140].

\subsubsection{Conservation Champions Are Major Players in Bringing Change}

Change is most effective when someone within the community, or with prior or current connection to the community, is convinced that some change is needed and is committed to mobilizing his or her fellow community members to take action. Such persons are generally known as "champions" for a cause, and can play an invaluable role. In many instances, engaging with and building the capacity of a charismatic conservation champion who is accepted by the community may be the most effective strategy that can be adopted to promote change. This person will play both bridging and translation roles, bringing different parties together and helping them to understand each other's perspectives, needs, limitations, and desires. A successful community conservation champion serves as a catalyst, often introducing innovative new ideas and bringing people together in constructive dialogue.

\subsubsection{Community Level Sense of Ownership and Commitment are Essential}

The value of personal and community-level commitment to environmental conservation cannot be overestimated. In some instances, an appreciation and commitment to sustainable use of resources is already present. Where it is not present-or has waned over time-early efforts should be placed on communications and outreach activities, as the fundamental purposes of any project intervention will not last much beyond a project's lifespan if such purposes are not suitably internalized. It is only with a sense of local ownership of decisions and actions that the durability of community members' involvement will be ensured. The mobilization of people for common purpose is often necessary, and this is usually most effective when calling on long-standing sociocultural norms and/or personal or community gain.

\subsubsection{Community Participation Increases Sense of Responsibility and Effectiveness}

Beyond inherent commitment to an idea or ideal, people also need to be involved in a project or activity for them to take on a fuller ownership of specific project outcomes, and conversely, to feel responsible when project outcomes are not being achieved. The level of community participation in a project also can feed back into people's commitment, which often can grow as dialogue amongst stakeholders improves and as communication and understanding increase. Participation generally is found in association with empowerment, improved management, and conservation success. 


\subsubsection{Community Co-Management Approaches Strengthen Actions and Build Trust}

In the context of natural resource management, including management of protected areas, "community co-management" has a proven track record of bringing together a wide range of stakeholders to the figurative table and strengthening partnerships for common purposes. More voices and perspectives can be heard, with wisdom often emerging from diversity. Although negotiation is always necessary, collective decisions and subsequent actions taken are generally more resilient and lasting. With rich evidence in the literature, Canada has made co-management with indigenous communities one of the mainstays of the federal national park system, and in Norway, co-management extends beyond natural resources and conservation to the governance of virtually all aspects of socioeconomic development. With sufficient time allowed for trust and understanding to develop, as witnessed in the Tibetan plateau region, more participatory models of development (collaborative management), including provision of social services (especially health and education; see [23,24]) have developed as local examples of wider application of co-management principles.

\subsubsection{Cooperatives and Associations Are Effective Tools for Common Action}

One of the richest forms of "participation" is when communities themselves decide and drive their own development and conservation programs. They may then choose to organize through the development of associations (mostly related to common purposes, interest groups, or professions) or by establishing cooperative enterprises that help members raise capital, coordinate their efforts, and maximize opportunities through collective action. Community cooperatives and associations have been shown in many instances also to serve as effective tools, inter alia, for the mobilization of both people and resources, strengthening of organizational capacities, and accessing of financial resources. In the Tibetan plateau region, recent prime examples include the strengthening of value chains (direct sale of yak wool to international markets) and alternative uses of natural aesthetic and cultural resources (development of community-beneficial tourism, such as ecotourism and adventure tourism operated by local community members).

\subsubsection{Citizen Science Can Serve as a Bridge between Communities and Government}

As government and public alike increasingly wish to adopt more evidence-based decision-making, the need for more information and data is evident everywhere. For managing natural resources-including wildlife and habitats in national parks-regular, repeated collection of data is necessary. However, limited financial and human resources preclude this possibility in nearly all instances; but, with the advent of new information and communications technologies (ICT), such as smartphones and dedicated applications, and also building on the recognized value of community participation in conservation, larger scale data collection than ever before is now possible. Collecting "big data" will help move decision-making from guesswork and five-year plans toward more real-time responsive assessments and strategic interventions. Involving grassroots stakeholders in deciding what should be monitored and researched, as well as in subsequent analysis and decision-making, will further increase people's sense of ownership, empowerment, and commitment to common conservation goals. A new era of science with society may be brought to fruition with use of ICTs, where political will is present.

From a conservation perspective, and expanding on models of "inclusive protected area management" developed elsewhere [33], the above principles and approaches may be summed up as being the key components of inclusive biodiversity conservation.

\section{Discussion}

\subsection{China's Belt and Road Initiative}

Building on the legacy of the ancient Silk Road through Central Asia that for generations allowed the movement and trade of goods (along with ideas, philosophies, religion) between China and 
Europe-and extending these to encompass many other routes and destinations, now including well over 60 countries with $70 \%$ of the world's population and nearly $30 \%$ of the global GDP [141,142] (Figure 11)—China has set the stage for a reshaping of international relations and globalization that is unprecedented in recent times. And, these new developments are here to stay. Not only has China recently enshrined Xi Jinping Thought on Socialism with Chinese Characteristics for a New Era into its constitution, but a lesser known amendment also was introduced with the statement that China will now be "following the principle of achieving shared growth through discussion and collaboration, and pursuing the Belt and Road Initiative" $[143,144]$. A new era has arrived and is now here to stay.

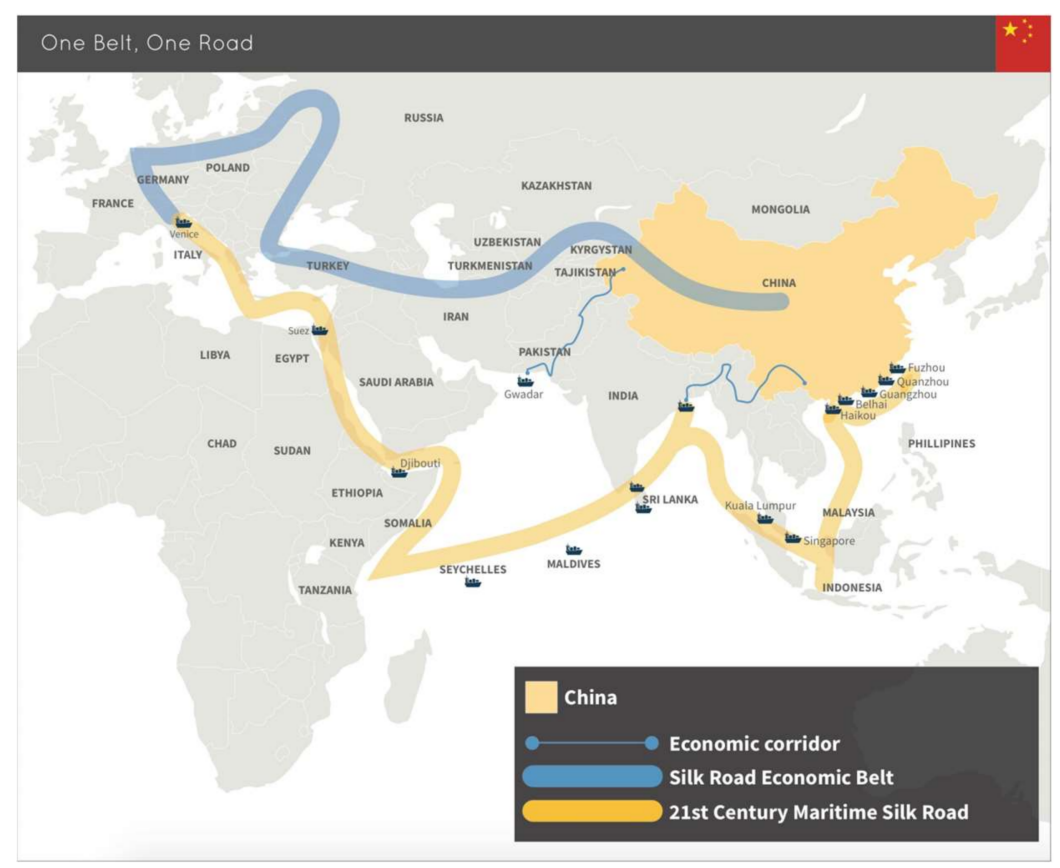

Figure 11. Geographic scope China's Belt and Road Initiative. Map by Peter Cai [141], reproduced with permission of the Lowy Institute, <https:/ / www.lowyinstitute.org/publications/ understandingbelt-and-road-initiative>.

The rationale for BRI is manifold, appearing either as "entirely a mercantile endeavor, designed to fortify China's economic interests around the world and open business opportunities for Chinese companies enduring a slowdown at home" [145]; or as a means for China "to address ... deepening regional disparity as [its] economy modernizes [with the hope that] its transnational infrastructure building program will spur growth in [its] underdeveloped hinterland and rustbelt" and as "platform to address the country's chronic excess capacity" [141]; or for China "to consolidate its position at the centre of global supply and manufacturing networks" [146]. At home, BRI is presented altruistically as "grounded in a philosophy of nations cooperating for mutual benefit, [with] no better strategy for worldwide growth, peace and stability" [147].

Whether used to "assert its leadership through a vast program of economic integration" [141] or seeking to achieve mutual benefit in ways that accommodate "the interests and concerns of all parties involved" through market operations [148] and with "promise of prosperity" [149], one way or another, China is bringing fresh geopolitical dimensions to international aid and development [11]. A range of BRI projects are already underway in Xinjiang Uyghur Autonomous Region, and many Chinese provinces are competing for BRI resources, and thus, have developed BRI-related plans [141]. Internationally, however, the potential opportunities and benefits along with challenges and costs of BRI for recipient countries beyond China's borders are much less obvious, having received significantly less attention to date (but see $[41,45,150])$. 
The Central Asian countries of Kazakhstan, Kyrgyzstan, and Tajikistan already are highly dependent on China for trade and the movement of goods, along with very high proportions of foreign direct investment coming from China (i.e., $72 \%$ and 37\% for Tajikistan and Kyrgyzstan, respectively, in 2016 [151]). Afghanistan is a country of substantial interest to all others in the region, due to security concerns, as well as substantial mineral and other natural resources. For its part, Pakistan already has a longer history of formal cooperation, through the development of the China-Pakistan Economic Corridor (CPEC). Further study and exploration of the local and regional opportunities offered by BRI, as well as potential impacts—including sociocultural, economic, and environmental—are just now starting to take place in greater depth (e.g., as introduced by [152], and further advanced at the Silk Roads crossing the mountains of Central Asia: Ancient routes and new challenges in times of global change workshop held in Dushanbe, Tajikistan on 3-4 October 2017, with recommendations presented in the Dushanbe Declaration [41]). ${ }^{11}$

Recognized as one of the world's biodiversity hotspots, the Mountains of Central Asia are now set to receive substantial investment from the Critical Ecosystem Partnership Fund (CEPF) supported by the European Union, the World Bank, MacArthur Foundation, and others [153] (Figure 12). As a meeting point of several vast biogeographic realms and with complex mountain topographies, this ecoregion has a unique, rich biodiversity. It also has a great diversity of peoples and cultures with well adapted rural livelihoods, a characteristic that is especially important in the context of climate change. What remains little known, though, is how China's BRI will intersect with local economies, ecological conditions, and cultures. Environmentally, there is some sense of hope [44,154,155], but some skepticism remains. Ultimately, "whether the new Silk Road brings environmental devastation or a new era of Chinese global resource stewardship and sustainable development will depend heavily on how China approaches the Belt and Road Initiative" [43].

\section{Mountains of Central Asia Biodiversity Hotspot}

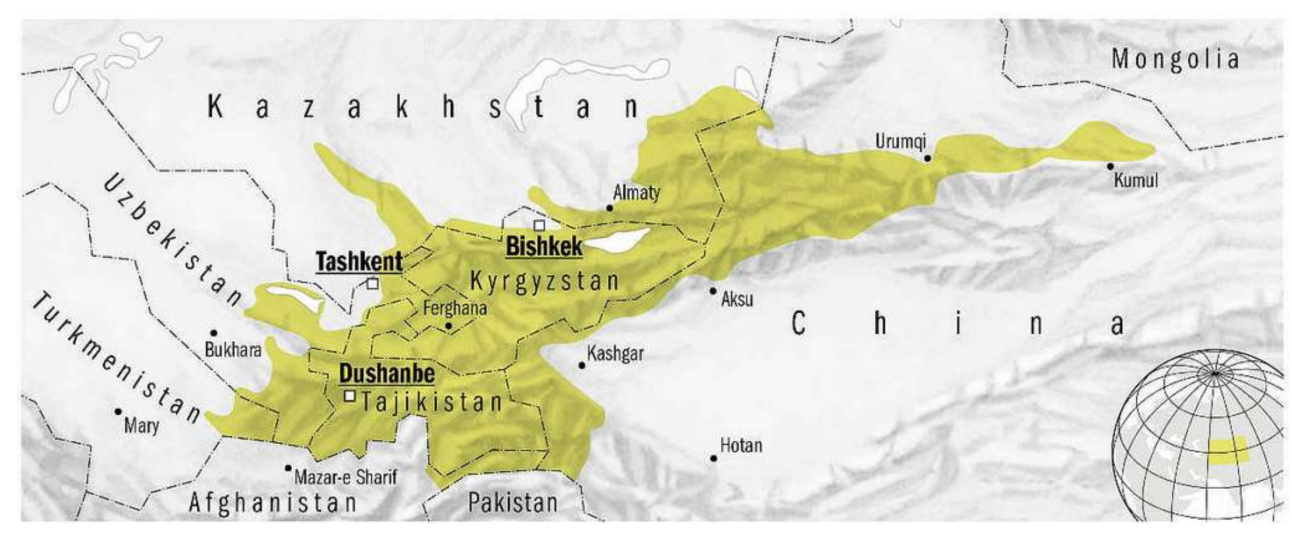

Figure 12. Mountains of Central Asia biodiversity hotspot [153]. Used with permission.

Ancient routes are being revived and recreated, and new approaches to international development and global relations have recently been launched in China-introducing a "new era" for a large part of the world and its population. For this reason, now is the time to revisit, consider and assess, and as appropriate to introduce lessons about environmental conservation and about sustainable community development-especially those learned in China, as presented herein-and begin to apply these to the international contexts beyond China's western borders, where it now is serving as one of the world's largest development partners.

11 See the Silk Roads in the Mountains of Central Asia workshop proceedings and the resulting Dushanbe Declaration at http: //ucentralasia.org/Research/Item/1625 and http:/ / ucentralasia.org/Research/Item/1626, respectively. 


\subsection{The Way Forward}

In China, the government has recently launched a new policy paradigm, ecological civilization, that calls on everyone at all levels to stop ignoring the environment in favor of the economy, and in fact, to pay much more attention to comprehensive environmental protection (see [156,157]). "The [Communist] party already accepts that [China's] environmental conditions need urgent improvements... The concept envisions better planning and carrying out future development within China's ecological capacity and rectifying degradation ... [prioritizing] pollution reduction, efficient use of natural resources, food security [and] climate change mitigation and adaptation" [158].

Clarifying and highlighting some of the key lessons learned over the past couple decades in China, especially in matters of use and protection of natural resources, both within and beyond protected areas, have been amongst the fundamental objectives of this article. These lessons have a potential application not only for China's emerging national parks system, but also for the ecosystems and landscapes in which protected areas are embedded. As China's global influence increases, particularly with its BRI programs in neighboring mountainous areas of Central Asia, how it views the environment and how such perspectives are integrated (or not) into development interventions is critically important for conservation. As rightfully queried, "Does China's intention to go through a 'green shift' domestically [also] resonate with these new transborder infrastructure development mega-projects?" [159]. How China chooses to operate, at home and abroad, will serve the interests or be detrimental to the interests of very large regions and enormous populations around the world.

More inclusive forms of biodiversity conservation in China-as outlined above-are encouraging, even if not perfectly developed, and consistent with the country's commitments as a signatory of the major global conventions (e.g., the Convention on Biological Diversity), and most recently, the UN Sustainable Development Goals (SDGs). The application of SDG principles and targets to its vast western mountainous regions has provided China with significant opportunity to consider various models and approaches-the learnings of which are now being incorporated, inter alia, in the trial development of its new national park system. Greater participation of communities with government authorities in the operations and to some extent the oversight of protected areas, in the monitoring and management of natural resources, and local socioeconomic development, are enabling new steps to be taken toward achieving the SDG goals-all 17 of the goals-but especially for Goal 15, Life on Land. These advances in more inclusive conservation should now be advocated also for wider application, both in and beyond protected areas, and wherever China has opportunity to bring its support $[29,33,44,98,160-162]$.

Specifically, the lessons learned "at home" in China should be leveraged to inform and guide future developments not only in the Sanjiangyuan region, but also more widely across the entire Tibetan Plateau environment [54], the vast grasslands and arid lands in western China [34,35,104,133], and even extending into the mountains of Central Asia, where China, through its BRI, is now playing a decisive role in shaping the future across multiple sectors and in many countries $[41,45,162]$.

Although mountains often may be viewed through the lens of geographic or politico-administrative borders and boundaries, they also can be special regions with not only ecological but also substantial sociocultural similarities $[163,164]$. For example, in the case of the Kirghiz and Wakhi people residing in four neighboring countries in the Pamir region, the similarities clearly outnumber their socioeconomic differences [53]. Likewise, there are many notable commonalities amongst yak herding communities across High Asia based on their mountain environments and livelihoods that exhibit a unifying effect (cf. sociocultural identity) extending far beyond formal language, nationality, or religion $[49,165,166]$.

Through BRI, China is now expanding its geographic scope and socioeconomic and political influence in unprecedented ways. Neighboring mountain areas in Central Asia are amongst the first locations to be considered and receive major BRI inputs, yet little is known about BRI impacts on the receiving side; most studies to date have focused mainly on global considerations or on motivations from China's perspective [45]. The introduction and application of lessons learned in China that are 
relevant to these receiving geographies and the potential impacts of BRI on the environment and local people and communities' socioeconomic development and wellbeing are, thus, highly pertinent. The recommendation is therefore hereby made that the lessons learned-as outlined above-should be considered carefully and incorporated into BRI planning and operations, both in western China and beyond its borders, with special reference to greater Central Asia with its cultural and linguistic diversity as well as its renowned Mountains of Central Asia biodiversity hotspot [153]. How China chooses to address environmental, sociocultural, and development concerns is critically important.

Three broad development themes finally emerge from the case study materials presented above, including the key lessons that have been extracted from experiences in the Sanjiangyuan region:

- Mountain livelihoods: Pastoralism as sustainable food system

- Protected area networks and regional/landscape conservation

- "Access and Benefit Sharing" through community co-management

These important thematic foci should in future be developed in even more detail, with the aim of informing development planning, including BRI, in more inclusive and environmentally friendly ways.

\subsubsection{Pastoralism Is a Sustainable Food System}

Pastoralism is not just an economic occupation; it is food production system, a livelihood, and often, a cultural identity [133]. Traditionally, pastoralism has been the primary means by which communities have transformed rangeland resources into basic sustenance. Pastoralism is, de facto, one of the most sustainable food systems on the planet, as it has proven by its very existence over many centuries, despite some long-standing entrenched prejudices and pressures from agricultural and urban populations [167]. The adaptive capacities of pastoralists have led them, through trial and error, to choose flexible and responsive decision-making processes and seasonally mobile land use patterns, allowing them to respond pragmatically to variable, often unpredictable, climatic conditions. This does not mean that misuse (including overuse) of natural resources and ensuing environmental degradation does not ever occur in rangelands, mediated, at least in part, by pastoral communities. However, where such land degradation occurs, it tends to have been influenced significantly by changing patterns of natural resource use, often due to an imposition (whether active or passive) of new sociopolitical structures or a diminishing of some features (or "design principles") that are commonly associated with a sustainable management of common pool resources [168-170]. Adopting more integrated perspectives on the interconnected social, economic, and ecological realities of rangelands and mountain ecosystems is increasingly recognized as of paramount importance to achieve sustainability $[171,172]$. Under management that properly links these complementary dimensions, pastoral food production systems can yet continue to serve the interests of both humanity and global biodiversity.

The United Nations Environment Programme (UNEP) and the International Union for the Conservation of Nature (IUCN) also highlight the role of pastoralists as stewards of more than a quarter of the world's total land area. Pastoralism is practiced by between 200 and 500 million people globally, including nomadic communities, transhumant herders, and agropastoralists. Yet, despite the large numbers, four important facts about pastoralism are widely overlooked [173]:

- Mobility of livestock (and wildlife) is essential to maintain the health of dryland ecosystemsfor carbon sequestration, watershed protection, and biodiversity conservation.

- Intensive livestock systems can degrade the environment by producing high levels of carbon dioxide and methane, polluting watercourses, and causing land degradation.

- Sustainable pastoral systems are more efficient, productive, and resilient than more sedentary agricultural systems in rangelands, when all factors and environmental benefits are counted.

- Pastoralism is a universal issue, as pastoralists in both the developing and developed countries share many environmental and economic challenges and opportunities. 
Additionally, the benefits derived from the sustainable use and preservation of rangelands can have regional and sometimes global facets, in particular, through upstream-downstream water linkages [22]. Pastoralism may also be recognized not only as a means to harvest resources, but in itself a cultural asset of mountain and rangeland social-ecological systems, as well as being provider of ecosystem services [172]. As outlined in the Convention on Biological Diversity's Good Practice Guide: Pastoralism, Nature Conservation and Development [174], "vegetation maintained through grazing activities...captures carbon, reduces erosion, maintains soils, facilitates water holding capacity and provides [wildlife] habitat. Most pastoral systems [also] are steeped in cultural practices and indigenous knowledge, 'cultural services' which are highly valued and often irreplaceable". Thus, even beyond the provision of direct goods and services, such as meat, milk, and fibers, pastoralism in the high altitude rangelands of the world may yet be a viable livelihood option, and "rather than abandoning pastoralism, the revitalisation of traditional practices and indigenous knowledge is vital to secure sustainable livelihoods for millions of pastoralists [worldwide] and to maintain rangeland biodiversity and ecosystem services" [175].

\subsubsection{Protected Area Networks and Regional/Landscape Level Conservation}

Not all conservation occurs within protected areas. Rather, long-term regional conservation can only be achieved when landscape level approaches are adopted, recognizing that a matrix of land use types is always present (including but not limited to protected areas), with many different stakeholder groups holding different perspectives and priorities. That said, protected areas do still have an important role to play, especially with a broadening of our understanding of the governance and management options available, including with indigenous and community conserved areas [28,176-183].

Strengthening the roles of protected areas in regional development planning and, more generally, mainstreaming the value of biodiversity across sectors have been advanced over the past decade through the work of organizations such as the United Nations Development Programme (UNDP), with support of the Global Environment Facility (GEF) and other financial instruments, including in Qinghai Province and Xinjiang Uyghur Autonomous Region of China, as well as Kyrgyzstan, Tajikistan, and elsewhere in Central Asia [184]. High level government support has been leveraged successfully in recent years, with a focus placed on one charismatic species, the snow leopard, as an icon of high mountain ecosystems. In this way, the Global Snow Leopard and Environmental Protection (GSLEP) program has clearly articulated many of the priority needs and opportunities for conservation of snow leopard landscapes, inclusive of local herding and nearby farming communities' interests and aspirations $[184,185]$. Key transboundary aspects of wildlife management in mountain regions, including illegal trade, also are highlighted in international political and academic discourses [186], and reflected in ongoing projects, such as the Hindu Kush Pamir Karakorum Transboundary Landscape Conservation project undertaken by the International Centre for Integrated Mountain Development (ICIMOD), the University of Central Asia (UCA), local protected areas, and a range of other partners in four countries [187].

In China, official plans state that national parks will be set up to achieve a combination of ecological protection and sustainable development goals, with a fine balance to be found between protection and utilization. Development opportunities should be available to local people within national parks, which will be possible, in part, because herders and farmers are now beginning to be recognized as major forces behind environmental protection, with "conservation" expected to provide jobs as well as increase local farmers' and herders' incomes [80]. Adopting such parallel and reinforcing perspectives will enable conservation to take place more widely, last longer (beyond single project cycles), and be more effective (through greater level of community engagement and "ownership" of plans and activities).

Broad landscape-level conservation perspectives, incorporating but not limited to national parks and other protected areas, ought to be applied more widely in western China (see $[34,104,133]$ ), 
and should equally be introduced as a fundamental pillar in China's BRI, in which biodiversity is becoming recognized more explicitly as core value [44].

\subsubsection{Access and Benefit Sharing (ABS) through Partnership and Co-Management}

Finally, access to natural resources and the ability to benefit from biodiversity-including land, water, and other natural resources-must not be compromised for local communities and governments with the arrival of new external stakeholders in the region. The development of genuine partnerships and community co-management approaches represent an ideal way forward, yet their application in reality is not always straightforward. Negotiations and compromises are always needed, and not every group has equal power or voice. In many places and ways in China, local voices are increasingly heard-but not uniformly or entirely, and not in every aspect of the new national parks systems. In the core areas of national parks, for example, local farmers and herders will need to relocate; for obvious reasons, reactions are mixed. ${ }^{12}$ When faced with relocations, herders in the Sanjiangyuan region have, themselves, struggled with reactions ranging from hopes for a better future for the next generation aided by new educational opportunities, to deep concern about how they should respond to such government policies (e.g., whether to sell their livestock and transition into a new way of life, or to "hold out" and lend their animals for a time to other family members or neighbors who plan to remain on the grassland), to sadness at anticipated loss of culture and traditional pastoral practices, to a general apprehension about all the change and challenges yet unknown $[13,23,24,55,60,64]$. At the same time, relative to the more strictly "protectionist" nature reserves in China (with their primary focus on nature conservation), the recent shift toward more collaborative approaches in management of protected areas and particularly the development of the national parks system in China (with its dual mandate, i.e., including both conservation and socioeconomic development) is promising in the trend that it represents. The positive elements identified in this review of environmental conservation in China over the past couple decades do not imply that all is perfect and improvements are not needed, but they do provide a focus for our corporate attention about some of the important foundations available, upon which to build future development programs and strategies, including especially China's BRI.

In short, conscientious attention must be given to ensure that infrastructure developments and business opportunities, as well as the management of protected areas, and in fact, any use of natural resources in the wider landscape, always be advanced in ways that bring greatest advantage to local communities and regions, and not be selected or promoted primarily on the basis of external drivers. Niche mountain products, tourism development, and value chains can also all be built to local and regional advantage. Special attention should equally be given to ensure that traditional knowledge and agrobiodiversity are preserved, both as protective adaptive mechanisms in the context of climate change, and to help anchor local communities and maintain cultural continuity in an era of rapid globalization [188-192]. Through such community-friendly approaches, greater equity in access to and sharing of the benefits derived from natural resources and other local assets can be maintained.

12 Although such mixed reactions are extremely important and must not be ignored, they are not the focus of this paperwhich instead has purposefully given most attention to the positive examples emerging from recent experiences in environmental conservation, such as the adoption of more integrated approaches and inclusive perspectives in natural resources management. The challenges associated with relocations can be enormous and deserve dedicated attention. For the present purposes, it shall suffice for now that this critical issue is noted as requiring further study, which should draw on local and global experiences surrounding "local communities" and their involvement in governance and management of natural resources and protected areas. In the present study, initial observations about perceptions and responses to relocations are based on numerous discussions with a wide range of actors over a period extending more than a decade, including local herders, community organizations, and national park field staff and leaders, as well as discussions with both natural science and social science specialists in China and internationally. Not surprisingly, perspectives and responses vary with people's positions and areas of specializations, with no single consensus emerging across all stakeholders. 


\section{Conclusions}

In all three broad thematic areas just outlined-i.e., pastoralism in a globalizing world, protected areas and landscape-level conservation, and sharing of the benefits of biodiversity and ecosystems - many valuable lessons have been learned in the past two decades in the Sanjiangyuan region, which could beneficially be applied more widely in western China, both within and outside protected areas, as well as internationally through the country's ambitious Belt and Road Initiative. How China now refines its broad plans and long-range ambitions across continents, especially in regard to their social and environmental impacts-whether as intended development benefits, or unforeseen side-effects of large-scale projects-these early months and years of the BRI will likely set the stage for years to come, and will both define China's position and, to some extent, its degree of acceptance in the global development community, and determine the long-term viability of its investments in infrastructure, transport and trade, agriculture, and other business opportunities.

The complexity of all the interrelated conservation and development issues and the multiple scales that are considered, from community to continental levels, clearly render any conclusions or recommendations tentative at best. However, broad outlines have emerged from China's own recent experiences with collaborative approaches in environmental conservation. These emerging views should now be considered in greater detail and integrated into the country's broader development programming at home and abroad. Communities, economies, and the environment all stand to gain.

Acknowledgments: No funding was received to conduct this review paper. Project grants for the conservation and development work undertaken by Plateau Perspectives in the Sanjiangyuan region, as outlined above, were received from multiple sources (more details are available on Plateau Perspectives' website, e.g., annual reports). No funds were received from any grant, personal or institutional, to cover the cost to publish in open access. For professional collaboration and other forms of support, special thanks are due to Marion Foggin and Alistair Foggin; to Tashi Dorje Hashil; to Gongbo Tashi, Jigme Rabden, and the Plateau Perspectives field team; and to many colleagues and advisors, donors, and government partners, along with a host of community members-too many to name individually, but all enormously appreciated. Additionally, for dialogues and support in better understanding the plans and possible implications of China's Belt \& Road Initiative, thanks are given to Troy Sternberg, Long Ruijun, Wu Ning, Yuri Badenkov, Hermann Kreutzmann, and others. In Central Asia, I also wish to thank my colleagues at University of Central Asia and especially at the Mountain Societies Research Institute, who introduced me over the past four years to Central Asia-its opportunities and challenges, as well as its people, politics, and environment. Finally, I express my genuine gratitude to Matthew Emslie-Smith, Chris Hergarten, and Stefanos Xenarios, who each have in different ways also have supported this writing project.

Conflicts of Interest: The authors declare no conflict of interest.

\section{References}

1. United Nations Department of Economic and Social Affairs. World Population Prospects: The 2017 Revision; United Nations: New York, NY, USA, 2017.

2. Ding, Y. Impacts of Affuence and Overexploitation of Natural Resources. In Environment and Development; Encyclopedia of Life Support Systems (EOLSS); Eolss Publishers Co. Ltd.; UNESCO: Oxford, UK, 2009; Volume 1.

3. Harris, P.G. Environmental Policy and Sustainable Development in China: Hong Kong in Global Context; University of Bristol Policy Press: Bristol, UK, 2012.

4. Mancini, M.S.; Galli, A.; Coscieme, L.; Niccolucci, V.; Lin, D.; Pulselli, F.M.; Bastianoni, S.; Marchettini, N. Exploring Ecosystem Services Assessment through Ecological Footprint Accounting. Ecosyst. Serv. 2018. [CrossRef]

5. Magalhães, P.; Steffen, W.; Bosselmann, K. The Need for an Integrated Assessment Framework to Account for Humanity's Pressure on the Earth System. In The Safe Operating Space Treaty: A New Approach to Managing Our Use of the Earth System; Cambridge Scholars Publishing: Newcastle, UK, 2016; pp. 213-245.

6. Steffen, W.; Richardson, K.; Rockström, J.; Cornell, S.E.; Fetzer, I.; Bennett, E.M.; Biggs, R.; Carpenter, S.R.; Vries, W.; Wit, C.A.; et al. Planetary Boundaries: Guiding Human Development on a Changing Planet. Science 2015, 347, 1259855. [CrossRef] [PubMed] 
7. United Nations General Assembly. Resolution 70/1: Transforming Our World: The 2030 Agenda for Sustainable Development. 2015. Available online: http://undocs.org/A/RES/70/1 (accessed on 27 October 2016).

8. Baker, S. China's Universities: Significant Progress, but More to Do. Times Higher Education (THE). Available online: https:/ / www.timeshighereducation.com/news/chinas-universities-significant-progressmore-do (accessed on 12 April 2018).

9. China Power Team. How Does Education in China Compare with Other Countries? Available online: https:/ / chinapower.csis.org/education-in-china/ (accessed on 15 March 2018).

10. High Quality Research Booming in China. Available online: https://www.natureindex.com/news-blog/ chart-chinas-top-ten-research-universities (accessed on 15 March 2018).

11. Kharas, H.; Rogerson, A. Global Development Trends and Challenges: Horizon 2025 Revisited; Overseas Development Institute: London, UK, 2017; p. 52.

12. Lin, Y.; Wang, Y. China's Growing Role in Global Development. China Daily. 12 May 2017. Available online: http:/ / www.chinadaily.com.cn/opinion/2017-05/12/content_29312577.htm (accessed on 15 March 2018).

13. Foggin, J.M. Highland Encounters: Building New Partnerships for Conservation and Sustainable Development in the Yangtze River Headwaters, Heart of the Tibetan Plateau. In Innovative Communities: People-Centred Approaches to Environmental Management in the Asia-Pacific Region; United Nations University (UNU) Press: Tokyo, Japan, 2005; p. 341.

14. Foggin, J.M. Promoting Biodiversity Conservation and Community Development in the Sanjiangyuan Region: Proceedings of Conservation Planning Meeting; Plateau Perspectives: Xining, China, 2005.

15. Tashi Dorje's Redemption. China Tibet Online. 9 November 2011. Available online: http://chinatibet.people. com.cn/96069/7639089.html (accessed on 15 March 2018).

16. Liu, J. Tibetan Environmentalists in China: The King of Dzi; Rowen, I.; Hui, C.K.; Yeh, E.T., Translators; Lexington Books: Lanham, MA, USA, 2015.

17. Foggin, J.M.; Phillips, J. Horizontal Policy Analysis: A Tool to Promote Sustainable Livelihoods Development; with Implications for Ecological Resettlement and Other Major Development Programs in the Tibetan Plateau Region. In Pastoralism in Contemporary China: Policy and Practice; Social Science Academic Press: Beijing, China, 2013; pp. 3-30.

18. Soini, K.; Birkeland, I. Exploring the Scientific Discourse on Cultural Sustainability. Geoforum 2014, 51, 213-223. [CrossRef]

19. Foggin, J.M. Biodiversity Protection and the Search for Sustainability in Tibetan Plateau Grasslands; Arizona State University: Tempe, AZ, USA, 2000.

20. Foggin, J.M. Building New Partnerships for Conservation E Sustainable Development in the Tibetan Plateau Region: Recent Experiences in the Yangtze River Headwaters; Plateau Perspectives: Xining, China, 2004; p. 14.

21. Foggin, M. Pastoralists and Wildlife Conservation in Western China: Collaborative Management within Protected Areas on the Tibetan Plateau. Pastor. Res. Policy Pract. 2012, 2, 17. [CrossRef]

22. Foggin, J.M. Conservation Issues: Mountain Ecosystems. In Reference Module in Earth Systems and Environmental Sciences; Elsevier: Toronto, ON, Canada, 2016; ISBN 978-0-12-409548-9. Available online: https:/ / doi.org/10.1016/B978-0-12-409548-9.09199-5 (accessed on 15 March 2018).

23. Foggin, M.; Torrance-Foggin, M. How Can Social and Environmental Services Be Provided for Mobile Tibetan Herders? Collaborative Examples from Qinghai Province, China. Pastor. Res. Policy Pract. 2011, 1, 21. [CrossRef]

24. Foggin, J.M.; Torrance-Foggin, M. Pastoralism, Development, and the Future of Tibetan Rangelands: Experiences in the Development and Provision of Social Services and Environmental Management. In Tibetan Pastoralists and Development: Negotiating the Future of Grassland Livelihoods; Reichert: Wiesbaden, Germany, 2017; pp. 175-186.

25. Shen, X.; Tan, J. Ecological Conservation, Cultural Preservation, and a Bridge between: The Journey of Shanshui Conservation Center in the Sanjiangyuan Region, Qinghai-Tibetan Plateau, China. Ecol. Soc. 2012, 17, 38. [CrossRef]

26. Agrawal, A. Common Property Institutions and Sustainable Governance of Resources. World Dev. 2001, 29, 1649-1672. [CrossRef]

27. Ballet, J.; Koffi, K.J.-M.; Komena, K.B. Co-Management of Natural Resources in Developing Countries: The Importance of Context, Abstract. Econ. Int. 2009, 120, 53-76. 
28. Borrini-Feyerabend, G.; Dudley, N.; Jaeger, T.; Lassen, B.; Pathak, B.N.; Phillips, A. Governance of Protected Areas: From Understanding to Action; Best Practice Protected Area Guidelines Series No. 20; IUCN: Gland, Switzerland, 2013; p. 124.

29. Du, W.; Penabaz-Wiley, S.M.; Njeru, A.M.; Kinoshita, I. Models and Approaches for Integrating Protected Areas with Their Surroundings: A Review of the Literature. Sustainability 2015, 7, 8151-8177. [CrossRef]

30. Kothari, A.; Corrigan, C.; Jonas, H.; Neumann, A.; Shrumm, H. Recognizing and Supporting Territories and Areas Conserved by Indigenous Peoples and Local Communities: Global Overview and National Case Studies; Technical Series no. 64; Secretariat of the Convention on Biological Diversity, ICCA Consortium, Kalpavriksh, and Natural Justice: Montreal, QC, Canada, 2012; p. 160.

31. Borrini-Feyerabend, G.; Hill, R. Governance for the Conservation of Nature. In Protected Area Governance and Management; ANU Press: Canberra, Australia, 2015; pp. 169-206.

32. Ervin, J.; Sekhran, N.; Dinu, A.; Gidda, S.; Vergeichik, M.; Mee, J. Protected Areas for the 21st Century: Lessons from UNDP/GEF's Portfolio; UNDP; CBD: Montreal, QC, Canada, 2010; p. 132.

33. Foggin, J.M. Managing Shared Natural Heritages: Towards More Participatory Models of Protected Area Management in Western China. J. Int. Wildl. Law Policy 2014, 17, 130-151. [CrossRef]

34. Harris, R.B. Wildlife Conservation in China: Preserving the Habitat of China's Wild West; M.E. Sharpe: London, UK, 2008.

35. Squires, V.; Hua, L.; Zhang, D.; Li, G. (Eds.) Towards Sustainable Use of Rangelands in North-West China; Springer: Dordrecht, The Netherlands, 2010; p. 353.

36. Liu, J.; Ouyang, Z.; Pimm, S.L.; Raven, P.H.; Wang, X.; Miao, H.; Han, N. Protecting China's Biodiversity. Science 2003, 300, 1240. [CrossRef] [PubMed]

37. McBeath, J.; McBeath, J.H. Biodiversity Conservation in China: Policies and Practice. J. Int. Wildl. Law Policy 2006, 9, 293-317. [CrossRef]

38. Liu, J.; Diamond, J. China's Environment in a Globalizing World. Nature 2005, 435, 1179. [CrossRef] [PubMed]

39. Wehrli, A. Why Mountains Matter for Sustainable Development. Mt. Res. Dev. 2014, 34, 405-409. [CrossRef]

40. Schmidt-Vogt, D.; Foggin, M.; Hergarten, C. Strengthening Mountain Societies in Central Asia in a Context of Multidimensional Change. Mt. Res. Dev. 2016, 36, 380-383. [CrossRef]

41. Foggin, J.M. Proceedings of International Workshop. Silk Roads in the Mountains of Central Asia: Ancient Routes $\mathcal{E}$ Modern Challenges in Times of Global Change; Mountain Societies Research Institute, University of Central Asia: Bishkek, Kyrgyzstan, 2018; Available online: http:/ / ucentralasia.org/Research/Item/1625 (accessed on 10 April 2018).

42. International Centre for Integrated Mountain Development (ICIMOD). Building Partnerships for Conservation and Development in HKH: Exploring Complementary Opportunities for Improving HKPL Transboundary Cooperation from One Belt, One Road Initiative, 1-12 December 2016, Lanzhou, China; ICIMOD: Kathmandu, Nepal, 2017; p. 39.

43. Pike, L. Will China's New Silk Road Be Green? Available online: https://www.chinadialogue.net/blog/ 9775-Explainer-Will-China-s-new-Silk-Road-be-green- / en (accessed on 15 March 2018).

44. Lechner, A.M.; Chan, F.K.S.; Campos-Arceiz, A. Biodiversity Conservation Should be a Core Value of China's Belt and Road Initiative. Nat. Ecol. Evol. 2018, 2, 408-409. [CrossRef] [PubMed]

45. Sternberg, T.; Ahearn, A.; McConnell, F. Central Asian 'Characteristics' on China's New Silk Road: The Role of Landscape and the Politics of Infrastructure. Land 2017, 6, 55. [CrossRef]

46. Maimaitiming, A.; Xiaolei, Z.; Huhua, C. Urbanization in Western China. Chin. J. Popul. Resour. Environ. 2013, 11, 79-86. [CrossRef]

47. Butler, R.A. The Top 10 Most Biodiverse Countries. Mongabay. Available online: https:/ / news.mongabay. com/2016/05/top-10-biodiverse-countries/ (accessed on 12 April 2018).

48. Wiener, G.; Jianlin, H.; Ruijun, L. The Yak, 2nd ed.; RAP. Publication; Regional Off. for Asia and the Pacific, Food and Agriculture Organization of the United Nations: Bangkok, Thailand, 2003.

49. Yak on the Move: Transboundary Challenges and Opportunities for Yak Raising in a Changing Hindu Kush Himalayan Region; Wu, N.; Yi, S.; Srijana, B.; Bisht, N. (Eds.) Special Publication; International Centre for Integrated Mountain Development (ICIMOD): Kathmandu, Nepal, 2016.

50. Rowntree, L.; Lewis, M.; Price, M.; Wycoff, W. Globalization and Diversity; Pearson: London, UK, 2016. 
51. Swanström, N.; Institute for Security and Development Policy; Silk Road Studies Program; Paul, H.; Nitze School of Advanced International Studies; Central Asia-Caucasus Institute. China and Greater Central Asia: New Frontiers; Silk Road Studies Program; Institute for Security and Development Policy: Stockholm, Sweden, 2011.

52. Squires, V.; Lu, Q. Sustainable Land Management in Greater Central AsialAn Integrated and Regional Perspective I Taylor E Francis Group, 1st ed.; Routledge: London, UK, 2017; p. 310.

53. Kreutzmann, H. Pamirian Crossroads: Kirghiz and Wakhi of High Asia; Harrassowitz Verlag: Wiesbaden, Germany, 2015.

54. Yao, T.; Thompson, L.G.; Mosbrugger, V.; Zhang, F.; Ma, Y.; Luo, T.; Xu, B.; Yang, X.; Joswiak, D.R.; Wang, W.; et al. Third Pole Environment (TPE). Environ. Dev. 2012, 3, 52-64. [CrossRef]

55. Foggin, J.M. Depopulating the Tibetan Grasslands. Mt. Res. Dev. 2008, 28, 26-31. [CrossRef]

56. Klein, J.A.; Yeh, E.; Bump, J.; Nyima, Y.; Hopping, K. Coordinating Environmental Protection and Climate Change Adaptation Policy in Resource-Dependent Communities: A Case Study from the Tibetan Plateau. In Climate Change Adaptation in Developed Nations; Advances in Global Change Research; Springer: Dordrecht, The Netherlands, 2011; pp. 423-438.

57. Long, R.; Ding, L.M.; Shang, Z.H.; Guo, X.H. The Yak Grazing System on the Qinghai-Tibetan Plateau and Its Status. Rangel. J. 2008, 30, 241-246. [CrossRef]

58. Miller, D. Grasslands of the Tibetan Plateau. Rangelands 1990, 12, 159-163.

59. Schaller, G.B. Wildlife of the Tibetan Steppe; University of Chicago Press: Chicago, IL, USA, 1998; p. 392.

60. Gruschke, A. Nomads without Pastures? Globalization, Regionalization, and Livelihood Security of Nomads and Former Nomads in Northern Khams. J. Int. Assoc. Tibet. Stud. 2008, 4, 1-40.

61. Sheehy, D.P.; Miller, D.; Johnson, D.A. Transformation of Traditional Pastoral Livestock Systems on the Tibetan Steppe. Secheresse 2006, 17, 142-151.

62. Shao, Q.; Jiyuan, L.I.U.; Lin, H.; Jiangwen, F.A.N.; Xinliang, X.U.; Junbang, W.; Quanqin, S.; Jiyuan, L.I.U.; Lin, H.; Jiangwen, F.A.N.; et al. Integrated Assessment on the Effectiveness of Ecological Conservation in Sanjiangyuan National Nature Reserve, Integrated Assessment on the Effectiveness of Ecological Conservation in Sanjiangyuan National Nature Reserve. Geogr. Res. 2013, 32, 1645-1656.

63. Yan, J.; Li, H.; Hua, X.; Peng, K.; Zhang, Y. Determinants of Engagement in Off-Farm Employment in the Sanjiangyuan Region of the Tibetan Plateau. Mt. Res. Dev. 2017, 37, 464-473. [CrossRef]

64. Du, F. Ecological Resettlement of Tibetan Herders in the Sanjiangyuan: A Case Study in Madoi County of Qinghai. Nomadic Peoples 2012, 16, 116-133. [CrossRef]

65. Xinhua. China to Invest $1 \mathrm{~b}$ Yuan in Sanjiangyuan National Park Construction. Available online: http: / / www.chinadaily.com.cn/china/2017-02/06/content_28117036.htm (accessed on 15 March 2018).

66. Foggin, J.M. Snow Leopard Landscape Conservation: Partnering with Local Communities in Western China and Central Asia for Conservation and Development. Available online: https:/ / bit.ly/2Hvx2Gg (accessed on 12 April 2018).

67. Xu, J.; Grumbine, R.E.; Shrestha, A.; Eriksson, M.; Yang, X.; Wang, Y.; Wilkes, A. The Melting Himalayas: Cascading Effects of Climate Change on Water, Biodiversity, and Livelihoods. Conserv. Biol. 2009, 23, 520-530. [CrossRef] [PubMed]

68. Kang, S.; You, Q.; Flugel, W.; Pepin, N.; Yan, Y.; Xu, Y.; Huang, J. Review of Climate and Cryospheric Change in the Tibetan Plateau. Environ. Res. Lett. 2010, 5, 15101. [CrossRef]

69. Li, X.-L.; Gao, J.; Brierley, G.; Qiao, Y.-M.; Zhang, J.; Yang, Y.-W. Rangeland Degradation on the Qinghai-Tibet Plateau: Implications for Rehabilitation. Land Degrad. Dev. 2013, 24, 72-80. [CrossRef]

70. Manandhar, S.; Xenarios, S.; Schmidt-Vogt, D.; Hergarten, C.; Foggin, J.M. Climate Vulnerability and Adaptive Capacity of Mountain Societies in Central Asia; MSRI Research Report Series; Research Report 1; Mountain Societies Research Institute, University of Central Asia: Bishkek, Kyrgyzstan, 2018.

71. Li, J.; Wang, W.; Axmacher, J.C.; Zhang, Y.; Zhu, Y. Streamlining China's Protected Areas. Science 2016, 351, 1160. [CrossRef] [PubMed]

72. Cao, M.; Peng, L.; Liu, S. Analysis of the Network of Protected Areas in China Based on a Geographic Perspective: Current Status, Issues and Integration. Sustainability 2015, 7, 15617-15631. [CrossRef]

73. Guo, Z.; Cui, G. Establishment of Nature Reserves in Administrative Regions of Mainland China. PLoS ONE 2015, 10, e0119650. [CrossRef] [PubMed] 
74. China Global Television Network (CGTN). How China's Ecological ‘Red Line' Fits into a Much Larger Plan. CGTN America. Available online: https:/ / america.cgtn.com/2017/03/10/how-chinas-ecological-red-linefits-into-a-much-larger-plan (accessed on 12 April 2018).

75. Yeh, E. Do China's Nature Reserves Only Exist on Paper? Available online: https:/ /www.chinadialogue.net/ article/show / single/en/6696-Do-China-s-nature-reserves-only-exist-on-paper- (accessed on 15 March 2018).

76. Wang, G.; Innes, J.L.; Wu, S.W.; Krzyzanowski, J.; Yin, Y.; Dai, S.; Zhang, X.; Liu, S. National Park Development in China: Conservation or Commercialization? Ambio 2012, 41, 247-261. [CrossRef] [PubMed]

77. Li, W.; Han, N. Ecotourism Management in China's Nature Reserves. AMBIO J. Hum. Environ. 2001, 30, 62-63. [CrossRef]

78. Eagles, P.; McCool, S.; Haynes, C. Sustainable Tourism in Protected Areas: Guidelines for Planning and Management; Best Practice Protected Area Guidelines Series; Best Practice Guidelines No 8; IUCN: Gland, Switzerland, 2002.

79. Xu, W.; Xiao, Y.; Zhang, J.; Yang, W.; Zhang, L.; Hull, V.; Wang, Z.; Zheng, H.; Liu, J.; Polasky, S.; et al. Strengthening Protected Areas for Biodiversity and Ecosystem Services in China. Proc. Natl. Acad. Sci. USA 2017, 114, 1601-1606. [CrossRef] [PubMed]

80. Zheng, J. First National Park Receiving Strong Legal and Financial Support. Available online: http:/ / english. gov.cn/news/top_news/2017/03/09/content_281475589549379.htm (accessed on 15 March 2018).

81. The Case for a National Park System in China. China Daily. Available online: http:/ / www.chinadaily.com. cn/china/2017-02/10/content_28165369.htm (accessed on 12 April 2018).

82. Liu, Q. China Overhauls Its National Parks. China Dialogue. Available online: https://www.chinadialogue. net/article/show/single/en/10152-China-overhauls-its-national-parks- (accessed on 12 April 2018).

83. China Council for International Cooperation on Environment and Development (CCICED). Ecological Civilization Shaping China's New Era; CCICED 2017 Issues Paper; CCICED: Beijing, China, 2017; p. 31.

84. Xinhua. China to Set Up National Park System. Available online: http://english.gov.cn/policies/policy_ watch/2017/09/27/content_281475888517430.htm (accessed on 15 March 2018).

85. Xinhua. China's First National Park to Open in 2020. Available online: http://www.xinhuanet.com/english/ 2018-01/18/c_136905975.htm (accessed on 15 March 2018).

86. China's National Parks: Natural, Scenic and Wild. Chinadaily Forum. 2017. Available online: http://bbs. chinadaily.com.cn/forum.php?mod=viewthread\&tid=1888641 (accessed on 15 March 2018).

87. Xiao, X. Discover China's 10 Pilot National Park. Available online: http:/ /discover.china.org.cn/trip-ideas/ discover-chinas-10-pilot-national-park/ (accessed on 15 March 2018).

88. Yan, W. China's First National Park, an Experiment in Living with Snow Leopards. Available online: https:/ / news.mongabay.com/2017/05/chinas-first-national-park-an-experiment-in-living-with-snowleopards / (accessed on 15 March 2018).

89. People's Daily Online. Protected Areas Identified for Construction of Great Wall National Park-People's Daily Online. Available online: http:/ /en.people.cn/n3/2017/1220/c90000-9306790.html (accessed on 15 March 2018).

90. Xinhua. Administration for Tiger and Leopard National Park Inaugurated. China Daily. Available online: http:/ / www.chinadaily.com.cn/china/2017-08/20/content_30851114.htm (accessed on 12 April 2018).

91. Ying. China Focus: China Plans National Park for Siberian Tiger, Amur Leopard. Available online: http: / / www.xinhuanet.com/english/2017-03/02/__136097346.htm (accessed on 12 April 2018).

92. China Council for International Cooperation on Environment and Development (CCICED). Progress in Environment and Development Policies in China and Impact of CCICED's Policy Recommendations (2013-2017); Progress Report; CCICED: Beijing, China, 2017; Available online: http:/ /www.cciced.net/cciceden/Events / AGM/2017/file/201712/P020171204411638362626.pdf (accessed on 15 March 2018).

93. Xinhua. China Approves 15 Regional Plans for Ecological “Red Lines". Available online: http://www. globaltimes.cn/content/1089447.shtml (accessed on 15 March 2018).

94. Li, Y.; Lu, C.; Lu, U.; Deng, O. Ecological Characteristics of China's Key Ecological Function Areas. J. Res. Ecol. 2015, 6, 427-432.

95. International Union for the Conservation of Nature (IUCN). Sustaining Development: IUCN and the Sustainable Development Goals; IUCN: Gland, Switzerland, 2017.

96. International Union for the Conservation of Nature (IUCN). Building the Sustainable Development Goals on the Aichi Biodiversity Targets; Sustainable Development Goals Policy Briefs Series; IUCN: Gland, Switzerland, 2017. 
97. Secretariat of the Convention on Biological Diversity (SCBD). Biodiversity and the 2030 Agenda for Sustainable Development Technical Note; Technical Note; Secretariat of the Convention on Biological Diversity: Montreal, QC, Canada, 2017.

98. Dudley, N.; Stolton, S.; Belokurov, A.; Krueger, L.; Lopoukhine, N.; MacKinnon, K.; Sandwith, T.; Sekhran, N. Natural Solutions-Protected Areas Helping People Cope with Climate Change; Report Funded and Commissioned by IUCN-WCPA, TNC, UNDP, WCS; World Bank; WWF: Gland, Switzerland; Washington, DC, USA; New York, NY, USA, 2009; p. 130.

99. Ministry of Foreign Affairs (MFA), People's Republic of China. China's Position Paper on the Implementation of the 2030 Agenda for Sustainable Development; Ministry of Foreign Affairs, PRC: Beijing, China, 2016. Available online: http://www.fmprc.gov.cn/mfa_eng/wjdt_665385/2649_665393/t1357701.shtml (accessed on 15 March 2018).

100. China Releases National Plan on Implementation of the 2030 Agenda for Sustainable Development. Available online: http://www.fmprc.gov.cn/mfa_eng/zxxx_662805/t1405596.shtml (accessed on 15 March 2018).

101. Leong, A. How the Paris Agreement and the SDGs Work Together. Available online: http://17goals.org/ paris-agreement-sdgs / (accessed on 15 March 2018).

102. Foggin, J.M. Kegawa Herders' Cooperative: Enhancing Community Resilience and Environmental Conservation in the Yangtze River Headwaters. 2016. Available online: https://www.slideshare.net/ marcfoggin/kegawa-herders-cooperative (accessed on 15 March 2018).

103. Breivik, I. The Political Ecology of Grassland Conservation in Qinghai Province. Master's Thesis, Norwegian University of Life Science, Ås, Norway, 2007. Available online: https: / tibetanplateau.wikischolars.columbia. edu/The+Political+Ecology+of+Grassland+Conservation+in+Qinghai+Province (accessed on 16 April 2018).

104. Shen, X.; Li, S.; Lu, Z. A New Approach to Conservation in Western China. In Green China: Chinese Insights on Environment and Development; Keeley, J., Yisheng, Z., Eds.; International Institute for Environment and Development: London, UK, 2011; pp. 118-135.

105. Shen, X.; Lu, Z.; Li, S.; Chen, N. Tibetan Sacred Sites: Understanding the Traditional Management System and Its Role in Modern Conservation. Ecol. Soc. 2012, 17, 13. [CrossRef]

106. Kassam, K.-A. Biocultural Diversity and Indigenous Ways of Knowing: Human Ecology in the Arctic; University of Calgary Press: Calgary, AL, Canada, 2009.

107. Salsberg, J.; Macridis, S.; Garcia Bengoechea, E.; Macaulay, A.C.; Moore, S. Engagement Strategies That Foster Community Self-Determination in Participatory Research: Insider Ownership. through Outsider Championship. Fam. Pract. 2017, 34, 336-340. [CrossRef] [PubMed]

108. Larson, C. A Model for Conservation in China? The Tibetan Antelope. Christian Science Monitor, 28 August 2012.

109. Xiao, H. Hoh Xil Heroes. China Pictorial. 8 August 2017. Available online: https:/ /www.pressreader.com/ china/china-pictorial-english/20170808/282458529077467 (accessed on 15 March 2018).

110. NewsChina. The Antelope and the Interloper. Available online: http://www.newschia/newschina/ articleDetail.do?article_id=2585\&section_id=\&magazine_id= (accessed on 15 March 2018).

111. Plateau Perspectives. Plateau Perspectives Annual Report 2005: Supporting Grassroots Initiatives in Conservation $\mathcal{E}$ Sustainable Development on the Tibetan Plateau; Annual Report; Plateau Perspectives: Saint-Lambert, QC, Canada, 2005; p. 24.

112. Plateau Perspectives. Plateau Perspectives Annual Report 2006: Supporting Community Development E Conservation on the Tibetan Plateau; Plateau Perspectives: Saint-Lambert, QC, Canada, 2006; p. 16.

113. Wei, Z. Tibetans Fight Back Against Declining "Reverence for Nature". Available online: https:/ / www.chinadialogue.net/article/show / single/en/5638-Tibetans-fight-back-against-decliningreverence-for-nature- (accessed on 15 March 2018).

114. Plateau Perspectives. Plateau Perspectives Annual Report 2007: Strategic Conservation, Building a Better Future; Plateau Perspectives: Saint-Lambert, QC, Canada, 2007; p. 24.

115. Plateau Perspectives. Plateau Perspectives Annual Report 2008: People E Nature: Working Together for a More Sustainable Future on the Tibetan Plateau; Plateau Perspectives: Saint-Lambert, QC, Canada, 2008; p. 16.

116. Plateau Perspectives. Plateau Perspectives Annual Report 2009: Hope for the Future; Annual Report; Plateau Perspectives: Saint-Lambert, QC, Canada, 2009. 
117. Plateau Perspectives. Plateau Perspectives Annual Report 2010: Rebuilding Yushu after the Earthquake; Annual Report; Plateau Perspectives: Saint-Lambert, QC, Canada, 2010.

118. Foggin, J.M. ICCAs as 'Contract Conservation' in the Chinese Tibetan Plateau Region. In Bio-Cultural Diversity Conserved by Indigenous Peoples E Local Communities-Examples E Analysis; Companion Document to IUCN/CEESP. Briefing Note 10: Strengthening What Works; ICCA Consortium, CENESTA, GEF, SGP, GTZ, IIED, IUCN/CEESP: Gland, Switzerland, 2010.

119. Plateau Perspectives. Snow Leopard Research and Conservation: Trialing New Forms of Collaborative Management in the Sanjiangyuan National Nature Reserve; Plateau Perspectives: Xining, China, 2011.

120. Plateau Perspectives. The Muqu Snow Leopard Conservation Project: Successful Trial of Collaborative Management in the SNNR; Plateau Perspectives: Xining, China, 2011.

121. Foggin, J.M. Local Communities and Conservation on the Tibetan Plateau: Two Case Studies of Collaborative Management in the Sanjiangyuan Region. In Proceedings of the International Symposium on the Human Dimensions of Ecological Conservation in the Tibetan Plateau Region, Xining, China, 21-26 August 2011; pp. 50-60.

122. United Nations Development Programme (UNDP), China. Strengthening the Effectiveness of the Protected Area System in Qinghai Province, China to Conserve Globally Important Biodiversity. Available online: http://www.cn.undp.org/content/china/en/home/operations/projects/environment_and_ energy/strengthening-the-effectiveness-of-the-protected-area-system-in-.html (accessed on 15 March 2018).

123. Plateau Perspectives. Plateau Perspectives Annual Report 2012: Building Community Resilience through Development of New Opportunities in the Tibetan Plateau Region; Annual Report; Plateau Perspectives: South Surrey, BC, Canada, 2012.

124. Plateau Perspectives. Plateau Perspectives Annual Report 2013; Annual Report; Plateau Perspectives: South Surrey, BC, Canada, 2013.

125. Plateau Perspectives. Plateau Perspectives Annual Report 2016; Annual Report; Plateau Perspectives: South Surrey, BC, Canada, 2016.

126. Foggin, J.M. Tibetan Herders Diversify Their Options. Farming Matters. 19 December 2016. Available online: https:/ / www.ileia.org/2016/12/19/locally-rooted-ideas-initiatives-field-17/ (accessed on 15 March 2018).

127. Plateau Perspectives. Plateau Perspectives Annual Report 2014; Annual Report; Plateau Perspectives: South Surrey, BC, Canada, 2014.

128. Plateau Perspectives. Plateau Perspectives Annual Report 2015; Annual Report; Plateau Perspectives: South Surrey, BC, Canada, 2015.

129. Holtz, M. Following Damage Caused by Economic Rise, China Tackles Ambitious Conservation Experiment. Christian Science Monitor, 20 August 2017.

130. Worthy, F.R.; Foggin, J.M. Conflicts between Local Villagers and Tibetan Brown Bears Threaten Conservation of Bears in a Remote Region of the Tibetan Plateau. Hum. Wildl. Confl. 2008, 2, 200-205.

131. Foggin, J.M.; Rabden, J. Trial Use of Electric Fencing to Prevent Intrusions by Tibetan Brown Bear. Int. Bear News 2010, 19, 15-18.

132. Plateau Perspectives. Plateau Perspectives Annual Report 2017; Annual Report; Plateau Perspectives: South Surrey, BC, Canada, 2017.

133. Hodges, J.; Foggin, M.; Long, R.; Zhaxi, G. Globalisation and the Sustainability of Farmers, Livestock-Keepers, Pastoralists and Fragile Habitats. Biodiversity 2014, 15, 109-118. [CrossRef]

134. Foggin, J.M.; Hergarten, C. Empowering Communities through Citizen Science: Giving Voice to under-Represented Societies through the Practice of Participatory Conservation and Environmental Monitoring. In Proceedings of the Citizen Science 2015, San Jose, CA, USA, 12-16 February 2015.

135. United Nations, Social Commission of the Economic and Social Council (Eleventh Session). Concepts and Principles of Community Development and Recommendations on Further Practical Measures to Be Taken by International Organizations. Ekistics 1957, 4, 92-96.

136. Sanders, I. Theories of Community Development. Rural Sociol. 1958, 23, 1-12.

137. Scoones, I. Sustainable Rural Livelihoods: A Framework for Analysis; IDS Working Paper Series; Institute of Development Studies: Brighton, UK, 1998; p. 22.

138. Brocklesby, M.A.; Fisher, E. Community Development in Sustainable Livelihoods ApproachesAn Introduction. Commun. Dev. J. 2003, 38, 185-198. [CrossRef] 
139. Naku, D.W.C.; Afrane, S. Local Community Development and the Participatory Planning Approach: A Review of Theory and Practice. Curr. Res. J. Soc. Sci. 2013, 5, 185-191.

140. Stafford-Smith, M.; Griggs, D.; Gaffney, O.; Ullah, F.; Reyers, B.; Kanie, N.; Stigson, B.; Shrivastava, P.; Leach, M.; O'Connell, D. Integration: The Key to Implementing the Sustainable Development Goals. Sustain. Sci. 2017, 12, 911-919. [CrossRef]

141. Cai, P. Understanding China's Belt and Road Initiative; Lowy Institute for International Policy: Sydney, Australia, 2017.

142. Campbell, C. Ports, Pipelines, and Geopolitics: China's New Silk Road Is a Challenge for Washington. Time. 23 October 2017. Available online: http:/ / time.com/4992103/china-silk-road-belt-xi-jinping-khorgoskazakhstan-infrastructure/ (accessed on 15 March 2018).

143. Shepherd, W. Why China Just Added the Belt and Road Initiative to Its Constitution. Available online: https:/ / www.forbes.com/sites/wadeshepard/2017/10/25/why-china-just-added-the-belt-and-roadinitiative-to-its-constitution/\#973bece42abc (accessed on 15 March 2018).

144. Xinhua. "Belt and Road" Incorporated into CPC Constitution. Available online: http:/ / www.xinhuanet. com/english/2017-10/24/c_136702025.htm (accessed on 15 March 2018).

145. Djankov, S.; Miner, S. China's Belt and Road Initiative: Motives, Scope \& Challenges; PIIE Briefing 16-2; Peterson Institute for International Economics: Washington, DC, USA, 2016; Available online: https://piie.com/ system/files/documents / piieb16-2_1.pdf (accessed on 15 March 2018).

146. Sajjanhar, A. China's Belt and Road Initiative: Prospects and Pitfalls; Institute for Defence Studies and Analyses. Available online: https://idsa.in/idsacomments/china-belt-and-road-initiative_asajjanhar_ 281117 (accessed on 15 March 2018).

147. South China Morning Post. Beijing's 'Belt and Road Initiative' Will Benefit the World. Available online: http:/ / www.scmp.com/comment/insight-opinion/article/2132943/beijings-belt-androad-initiative-will-benefit-world (accessed on 15 March 2018).

148. State Council of the People's Republic of China (SCPRC). Full Text: Action Plan on the Belt and Road Initiative; Action Plan; State Council of the People's Republic of China: Beijing, China, 2015. Available online: http:/ / english.gov.cn/archive/publications/2015/03/30/content_281475080249035.htm (accessed on 15 March 2018).

149. Ying, F. China's New Silk Road Promises Prosperity across Eurasia. Huffington Post. 31 July 2015. Available online: https://www.huffingtonpost.com/fu-ying/china-silk-road-eurasia_b_7899236.html (accessed on 15 March 2018).

150. Dörre, A.; Kreutzmann, H.; Schütte, S. Pamirs at the Crossoads: Changing Challenges and Perspectives; Berlin Geographical Papers; Center for Development Studies: Berlin/Heidelberg, Germany, 2016.

151. RICA Network. Available online: http://www.rica.network/publications/monthly-reports (accessed on 15 March 2018).

152. Badenkov, Y. Closing Statement and Remarks on Future Perspectives. In Pamirs at the Crossroads: Changing Challenges and Perspectives; Springer: Berlin/Heidelberg, Germany, 2016; pp. 89-100.

153. Critical Ecosystems Partnership Fund (CEPF). Mountains of Central Asia Biodiversity Hotspot; Ecosystem Profile; CEPF: Arlington, VA, USA, 2017; p. 184.

154. Nichols, S. China's New Silk Road Offers Environmental Promise. Available online: http://research.msu. edu/yesterdays-silk-road-tomorrows-environmental-superhighway/ (accessed on 15 March 2018).

155. Nichols, S. Yesterday's Silk Road could be Tomorrow's Environmental Superhighway. Available online: http:/ / msutoday.msu.edu/news/2016/yesterdays-silk-road-could-be-tomorrows-environmentalsuperhighway/ (accessed on 15 March 2018).

156. Zhang, C. China's New Blueprint for an "Ecological Civilization". The Diplomat, 30 September 2015.

157. Xiao, L.; Zhao, R. China's New Era of Ecological Civilization. Science 2017, 358, 1008-1009. [PubMed]

158. Loh, C. Green Policies in Focus as China's Rise to an Ecological Civilisation Continues Apace. South China Morning Post. 11 October 2017. Available online: http:/ / www.scmp.com/comment/insight-opinion/article/ 2114748/green-policies-focus-chinas-rise-ecological-civilisation (accessed on 15 March 2018).

159. Tracy, E.F.; Shvarts, E.; Simonov, E.; Babenko, M. China's New Eurasian Ambitions: The Environmental Risks of the Silk Road Economic Belt. Eurasian Geogr. Econ. 2017, 58, 56-88. [CrossRef] 
160. Neupane, S. Community Engagement in the SDG Era and the Role of Development Donors. Available online: http:/ / www.thinktankinitiative.org/blog/community-engagement-sdg-era-and-roledevelopment-donors (accessed on 15 March 2018).

161. Howard, J.; Wheeler, J. What Community Development and Citizen Participation Should Contribute to the New Global Framework for Sustainable Development. Commun. Dev. J. 2015, 50, 552-570. [CrossRef]

162. Laruelle, M. (Ed.) China's Belt and Road Initiative and Its Impact in Central Asia; The George Washington University, Central Asia Program: Washington, DC, USA, 2018.

163. Debarbieux, B.; Rudaz, G. Linking Mountain Identities throughout the World: The Experience of Swiss Communities. Cult. Geogr. 2008, 15, 497-517. [CrossRef]

164. Aga Khan, H.H. Speech by His Highness the Aga Khan. Available online: http://ismaili.net/timeline/2000/ 000605/pakspeech06001.html (accessed on 15 March 2018).

165. Carralero Benitez, S. World Yak Herders Association: Community Dialogues in High Asia. Report for FAO Pastoralism Knowledge Hub; YURTA Association: Malaga, Spain, 2017.

166. Tsering, S. Whither the Tsampa Eater. Himāl 1993, 6, 8-11.

167. Krätli, S.; Schareika, N. Living off Uncertainty: The Intelligent Animal Production of Dryland Pastoralists. Eur. J. Dev. Res. 2010, 22, 605-622. [CrossRef]

168. Anderies, J.; Janssen, M.; Ostrom, E. A Framework to Analyze the Robustness of Social-Ecological Systems from an Institutional Perspective. Ecol. Soc. 2004, 9, 18. [CrossRef]

169. Ostrom, E. A General Framework for Analyzing Sustainability of Social-Ecological Systems I Science. Science 2009, 325, 419-422. [CrossRef] [PubMed]

170. Ostrom, E. Background on the Institutional Analysis and Development Framework: Ostrom: Institutional Analysis and Development Framework. Policy Stud. J. 2011, 39, 7-27. [CrossRef]

171. Sukhdev, P.; Bishop, J.; Ten Brink, P.; Gundimeda, H.; Karousakis, K.; Kumar, P.; Neßhöver, C.; Neuville, A.; Skinner, D.; Vakrou, A.; et al. The Economics of Ecosystems \& Biodiversity: An Interim Report; European Communities: Wesseling, Germany, 2008.

172. McGahey, D.; Davies, J.; Hagelberg, N.; Ouedraogo, R. Pastoralism and the Green Economy—A Natural Nexus? International Union for the Conservation of Nature (IUCN); United Nations Environment Programme (UNEP): Nairobi, Kenya, 2014; p. 58.

173. Davies, J.; Hagelberg, N. Sustainable Pastoralism and the Post 2015 Agenda: Opportunities and Barriers to Pastoralism for Global Food Production and Environmental Stewardship; United Nations Environment Programme (UNEP); International Union for the Conservation of Nature (IUCN): Gland, Switzerland, 2015; p. 2.

174. Secretariat of the Convention on Biological Diversity (SCBD). Pastoralism, Nature Conservation and Development: A Good Practice Guide; Secretariat of the Convention on Biological Diversity: Montreal, QC, Canada, 2010.

175. Seid, M.A.; Kuhn, N.J.; Fikre, T.Z. The Role of Pastoralism in Regulating Ecosystem Services: -EN-FR-Le Rôle Du Pastoralisme Dans La Réglementation Des Services Écosystémiques -ES- La Función Del Pastoreo En La Regulación de Los Servicios Ecosistémicos. Revue Scientifique et Technique de l'OIE 2016, 35, 435-444. [CrossRef] [PubMed]

176. Borrini-Feyerabend, G.; Pimbert, M.; Farvar, T.; Kothari, A.; Renard, Y. Sharing Power: Learning by Doing in Co-Management of Natural Resources throughout the World; IIED and IUCN/CEESP: Gland, Switzerland, 2004.

177. Borrini-Feyerabend, G.; Kothari, A. Recognising and Supporting Indigenous \& Community Conservation-Ideas $\mathcal{E}$ Experiences from the Grassroots; CEESP Briefing Note 9; IUCN: Gland, Switzerland; p. 28.

178. Corrigan, C.; Granziera, A. A Handbook for the Indigenous and Community Conserved Areas Registry; UNEP-WCMC: Cambridge, UK, 2010.

179. Lockwood, M.; Worboys, G.; Kothari, A. (Eds.) Managing Protected Areas: A Global Guide; Routledge: London, UK, 2006.

180. Worboys, G.L.; Kothari, A.; Pulsford, I.; Lockwood, M.; Feary, S. Protected Area Governance and Management; ANU Press: Canberra, Australia, 2015.

181. Dinerstein, E.; Olson, D.; Joshi, A.; Vynne, C.; Burgess, N.D.; Wikramanayake, E.; Hahn, N.; Palminteri, S.; Hedao, P.; Noss, R.; et al. An Ecoregion-Based Approach to Protecting Half the Terrestrial Realm. BioScience 2017, 67, 534-545. [CrossRef] [PubMed]

182. Baldwin, R.F.; Trombulak, S.C.; Leonard, P.B.; Noss, R.F.; Hilty, J.A.; Possingham, H.P.; Scarlett, L.; Anderson, M.G. The Future of Landscape Conservation. BioScience 2018, 68, 60-63. [CrossRef] [PubMed] 
183. Infield, M.; Entwistle, A.; Anthem, H.; Mugisha, A.; Phillips, K. Reflections on Cultural Values Approaches to Conservation: Lessons from 20 Years of Implementation. Oryx 2017, 52, 1-11. [CrossRef]

184. Paxton, M.; Scott, T.; Watanabe, Y. Silent Roar: UNDP. E GEF in the Snow Leopard Landscape; United Nations Development Program: Washington, DC, USA, 2016; p. 48.

185. Jackson, R.M. HWC Ten Years Later: Successes and Shortcomings of Approaches to Global Snow Leopard Conservation. Hum. Dimens. Wildl. 2015, 20, 310-316. [CrossRef]

186. Vasilijević, M.; Zunckel, K.; McKinney, M.; Erg, B.; Schoon, M.; Rosen Michel, T. Transboundary Conservation: A Systematic and Integrated Approach; Groves, C., Phillips, A., Eds.; International Union for Conservation of Nature (IUCN): Gland, Switzerland, 2015.

187. International Centre for Integrated Mountain Development (ICIMOD). Hindu Kush Karakoram Pamir Landscape Conservation and Development Initiative; ICIMOD: Kathmandu, Nepal, 2016.

188. Johns, T.; Powell, B.; Maundu, P.; Eyzaguirre, P.B. Agricultural Biodiversity as a Link between Traditional Food Systems and Contemporary Development, Social Integrity and Ecological Health. J. Sci. Food Agric. 2013, 93, 3433-3442. [CrossRef] [PubMed]

189. Mijatovic, D.; Van Oudenhouven, F.; Eyzaguirre, P.; Hodgkin, T. The Role of Agricultural Biodiversity in Strengthening Resilience to Climate Change: Towards an Analytical Framework. Int. J. Agric. Sust. 2012, 11, 95-107. [CrossRef]

190. Van Oudenhouven, F.; Mijatovic, D.; Eyzaguirre, P. Bridging Managed and Natural Landscapes; Bioversity International: Rome, Italy, 2009; p. 1.

191. Zimmerer, K.S. Agriculture, Livelihoods, and Globalization: The Analysis of New Trajectories (and Avoidance of Just-so Stories) of Human-Environment Change and Conservation. Agric. Hum. Values 2007, 24, 9-16. [CrossRef]

192. Amend, T.; Brown, J.; Kothari, A.; Phillips, A.; Stolton, S. (Eds.) Protected Landscapes and Agrobiodiversity Values. Values of Protected Landscapes and Seascapes. Available online: https://www.cbd.int/doc/pa/ tools/Values\%20of\%20Protected\%20Landscapes\%20and\%20Seascapes.pdf (accessed on 15 March 2018).

(C) 2018 by the author. Licensee MDPI, Basel, Switzerland. This article is an open access article distributed under the terms and conditions of the Creative Commons Attribution (CC BY) license (http:/ / creativecommons.org/licenses/by/4.0/). 